Atmos. Chem. Phys., 10, 6063-6086, 2010

www.atmos-chem-phys.net/10/6063/2010/

doi:10.5194/acp-10-6063-2010

(C) Author(s) 2010. CC Attribution 3.0 License.

\title{
Long range transport of mercury to the Arctic and across Canada
}

\author{
D. Durnford, A. Dastoor, D. Figueras-Nieto, and A. Ryjkov
}

Air Quality Research Division, Environment Canada, 2121 TransCanada Highway, Dorval, QC, H9P 1J3, Canada

Received: 17 December 2009 - Published in Atmos. Chem. Phys. Discuss.: 16 February 2010

Revised: 26 May 2010 - Accepted: 14 June 2010 - Published: 6 July 2010

\begin{abstract}
This study is the most extensive study to date on the transport of mercury to the Arctic. Moreover, it is the first such study to use a fully-coupled, online chemical transport model, Environment Canada's Global/Regional Atmospheric Heavy Metals model (GRAHM), where the meteorology and mercury processes are fully integrated. It is also the only study to date on the transport of mercury across Canada. We estimated source attribution from Asia, North America, Russia and Europe at six arctic verification stations, as well as three subarctic and eight midlatitude Canadian stations.
\end{abstract}

We have found that Asia, despite having transport efficiencies that were almost always lower than those of North America and often lower than those of Russia, was the dominant source of gaseous atmospheric mercury at all verification stations: it contributed the most mercury (29-37\% at all stations, seasons and levels considered), its concentrations frequently explained nearly $100 \%$ of the variability in the concentrations produced by the simulation performed with full global emissions, particularly in the absence of local sources, and it generated the most long range transport (LRT) events, causing $43 \%, 67 \%$ and $75 \%$ of the events at the arctic, subarctic and midlatitude stations, respectively. For the Arctic, Russian transport efficiencies tended to be the strongest, as expected, while European and Asian efficiencies were lower and higher, respectively, than those found in the literature. This disagreement is likely produced by mercury's long lifetime relative to that of other pollutants. The accepted springtime preference for the trans-Pacific transport of Asian pollution was evident only in the midlatitude group of stations, being masked in the arctic and subarctic groups by the occurrence of atmospheric mercury depletion events. Some

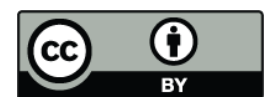

Correspondence to: D. Durnford (dorothy.durnford@ec.gc.ca) neighbouring arctic stations recorded dissimilar numbers of LRT events; despite their proximity, the behaviour of mercury at these stations was governed by different dynamics and transport pathways. The column burden of GEM in the lowest $5 \mathrm{~km}$ of the Northern Hemisphere was largest in summer from Asia, North America and Russia, but in winter from Europe. In the vertical, transport of mercury from all source regions occurred principally in the mid-troposphere.

\section{Introduction}

Gaseous elemental mercury (GEM) can be converted to a potent bioaccumulating neuro-toxin, methylmercury, in the presence of bacteria. Methylation can occur in watery environments including oceans (Sunderland et al., 2009), freshwater wetlands (Goulet et al., 2007) and peatlands (Mitchell et al., 2008a). Consuming fish with elevated levels of methylmercury can cause severe health problems in humans (Sunderland et al., 2009).

Mercury is emitted into the atmosphere from natural deposits on land and in oceans and as a result of anthropogenic activity. Once in the atmosphere, it is advected by winds. Since the lifetime of GEM has been estimated at between 6 months and 2 years (Strode et al., 2008; Lin et al., 2006, Schroeder and Munthe, 1998), it can be transported considerable distances from its source region. Oxidation of GEM produces reactive gaseous mercury (RGM) and mercury associated with particles (PHg) (Lin et al., 2006), which only have lifetimes on the order of days (Faïn et al., 2009; Schroeder and Munthe, 1998). Deposition occurs through scavenging by precipitation, and also as a result of dry processes. Once deposited, RGM and PHg may reduce to GEM and be reemitted (Steen et al., 2009). The repetition of the deposition and reemission cycle constitutes mercury's so-called grasshopper

Published by Copernicus Publications on behalf of the European Geosciences Union. 
motion (Almeida et al., 2005). Thus, mercury that is emitted in one part of the world can eventually be transported to any other location. Mercury deposition in Arctic Alaska has increased three-fold since the advent of the Industrial Revolution (Fitzgerald et al., 2005).

In this study, we model the long range transport (LRT) of mercury to multiple observation stations around the Arctic, as well as to subarctic and midlatitude stations across Canada. This investigation is a component of the International Polar Year (IPY) project, Intercontinental Atmospheric Transport of Anthropogenic Pollutants to the Arctic (INCATPA). By running our model with global emissions and with emissions from a specified source region alone, we are able to estimate source attribution. Previous work on the long range transport of mercury includes studies on: trans-Pacific transport (Strode et al., 2008; Radke et al., 2007; Weiss-Penzias et al., 2006, 2007; Jaffe et al., 2005); transport within the Arctic (Berg et al, 2008); over Europe (Ryaboshapko et al., 2007a, b); and in the Northern Hemisphere (Travnikov, 2005). Other relevant studies, including those by Wang et al. (2009), Shindell et al. (2008), Jiang et al. (2007), Stohl (2006), and Liang et al. (2004), investigated the long range transport of carbon monoxide and other gaseous pollutants and/or aerosols. Of the mercury studies, only the GRAHM, which participated in the Ryaboshapko et al. (2007a, b) studies, and which is used in this project, is an online, fully-coupled model, such that the meteorology and mercury processes are fully integrated. Our study is also of interest in that it represents the most extensive study to date on the transport of mercury both to the Arctic and across Canada. The study also serves as an evaluation of the model, particularly in the Arctic. Meteorological and mercury processes are highly heterogeneous. Verification at multiple sites tests all processes simultaneously. This provides a large scale view of the model's performance and aids future model development. This study focuses on the long range transport of mercury; deposition will be the focus of a forthcoming companion paper.

Background information is provided in Sect. 2. In Sect. 3, we discuss ambient mercury concentrations at individual verification stations, investigating the behaviour of source attribution. We also investigate preferred mercury transport pathways through two-dimensional fields. A Summary is presented in Sect. 4.

\section{Methodology}

\subsection{Data}

\subsubsection{Observations}

We verified our model's simulation of surface-level atmospheric mercury concentrations against observations at 17 stations (Fig. 1, Table 1). In order to highlight latitudinal

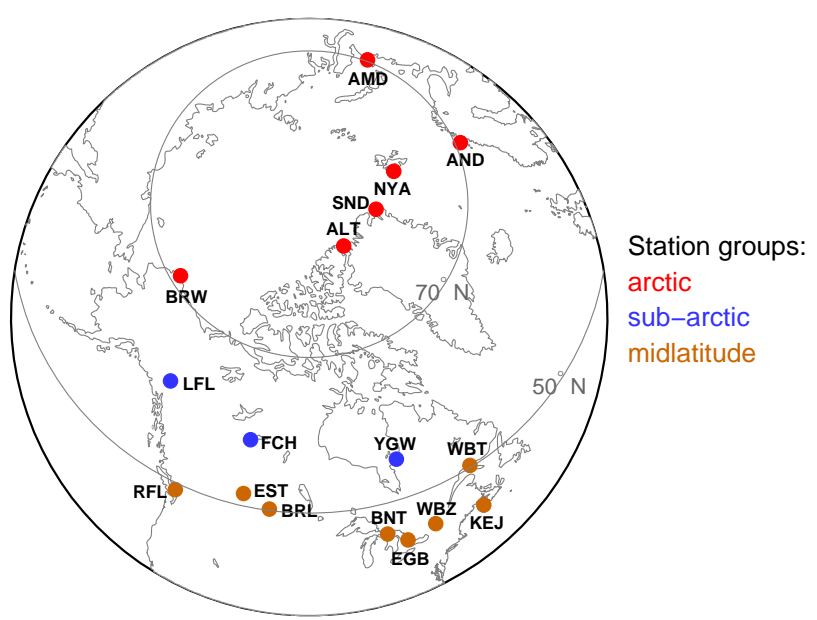

Fig. 1. Locations of verification stations. See Table 1 for station names.

variations in mercury transport, we divided the 17 stations into three groups: arctic (six stations), subarctic (three stations) and midlatitude (eight stations). The arctic stations are situated throughout the Arctic, while the subarctic and midlatitude stations are in Canada alone. The stations range in altitude from sea level to $1.1 \mathrm{~km}$ above sea level.

Years with as complete a dataset as possible and close to 2000 or 2005 were chosen for verification; the anthropogenic emissions used are valid in 2000 and 2005 (see Sect. 2.1.2). It would be helpful if there were a dataset of mercury observations from all our stations during a single year, as this would eliminate meteorological inter-annual variability. Given that such a dataset does not yet exist, we chose to use multiple verification stations despite the range of years; evaluating model performance at multiple locations is highly beneficial for model development as it tests whether model meteorological and chemical processes work equally well under varying conditions. Furthermore, given the multiple years used, our statistical results could be interpreted as representing an average model performance during varying meteorological conditions; different atmospheric conditions occur in different years. Note that the model performance is always compared to the year as well as the location of each set of observations.

Observations at all six arctic stations are of GEM. It is a matter of debate whether the form of mercury measured by the Tekran 2537 instrument (Swartzendruber et al., 2009) at the subarctic and midlatitude stations is GEM or total gaseous mercury (TGM). This debate is unfortunate. We will arbitrarily label the mercury at the subarctic and midlatitude stations as TGM. If it actually is GEM that is measured at these stations, the only consequence to our results would be that our base run TGM concentrations might occasionally be elevated with respect to the GEM observations at verification stations that are close to a local source. 
Table 1. Verification stations.

\begin{tabular}{|c|c|c|c|c|c|c|c|}
\hline Station & $\begin{array}{l}\text { Station } \\
\text { identifier }\end{array}$ & $\begin{array}{r}\text { Latitude } \\
\left({ }^{\circ} \mathrm{N}\right)\end{array}$ & $\begin{array}{r}\text { Longitude } \\
\left({ }^{\circ} \mathrm{E}\right)\end{array}$ & $\begin{array}{r}\text { Elevation } \\
(\mathrm{m})\end{array}$ & $\begin{array}{l}\text { Observed } \\
\text { species }\end{array}$ & $\begin{array}{l}\text { Verification } \\
\text { year }\end{array}$ & $\begin{array}{l}\text { Data } \\
\text { source }\end{array}$ \\
\hline \multicolumn{8}{|c|}{ Arctic stations } \\
\hline Barrow, USA & BRW & 71.3 & -156.8 & 9 & GEM & 2000 & Steve Brooks, National Oceanic and Atmospheric Administration, USA \\
\hline Alert, Canada & ALT & 82.5 & -62.3 & 210 & GEM & 2000 & CAMNet, http://www.msc-smc.ec.gc.ca/natchem/index_e.html, Canada \\
\hline Station Nord, Greenland & SND & 81.6 & -16.7 & 20 & GEM & 2001 & Henrik Skov, National Environmental Research Institute, Denmark \\
\hline Ny-Ålesund, Norway & NYA & 78.9 & 11.9 & 474 & GEM & 2008 & Katrine Aspmo, Pfaffhuber, Norwegian Institute for Air Research, Norway \\
\hline Andoya, Norway & AND & 69.0 & 16.0 & 380 & GEM & 2004 & Torunn Berg, Norwegian Institute for Air Research, Norway \\
\hline Amderma, Russia & AMD & 69.8 & 61.7 & 41 & GEM & 2008 & Alexandra Steffen, Environment Canada \\
\hline \multicolumn{8}{|c|}{ Sub-arctic stations } \\
\hline Little Fox Lake & LFL & 61.4 & -135.6 & 1128 & TGM & 2008 & Alexandra Steffen, Environment Canada \\
\hline Fort Chipewyan & $\mathrm{FCH}$ & 58.8 & -111.1 & 232 & TGM & 2001 & Canadian National Atmospheric Chemistry Database, \\
\hline Kuujjuarapik & YGW & 55.3 & -77.7 & 14 & TGM & 2006 & http://www.msc-smc.ec.gc.ca/natchem/index_e.html, Canada \\
\hline \multicolumn{8}{|c|}{ Midlatitude stations } \\
\hline Reifel Island (or Delta) & RFL & 49.1 & -123.2 & 0 & TGM & 2000 & Canadian National Atmospheric Chemistry Database, \\
\hline Esther & EST & 51.7 & -110.2 & 707 & TGM & 2000 & http://www.msc-smc.ec.gc.ca/natchem/index_e.html, Canada \\
\hline Bratt's lake & BRL & 50.2 & -104.7 & 587 & TGM & 2006 & \\
\hline Burnt Island & BNT & 45.8 & -83.0 & 75 & TGM & 2000 & \\
\hline Egbert & EGB & 44.2 & -79.8 & 251 & TGM & 2000 & \\
\hline St. Anicet & WBZ & 45.1 & -74.3 & 49 & TGM & 2005 & \\
\hline Kejimkujik & KEJ & 44.4 & -65.2 & 127 & TGM & 2001 & \\
\hline Mingan & WBT & 50.3 & -64.2 & 11 & TGM & 2000 & \\
\hline
\end{tabular}

Since this study focuses on long range transport, we smooth the observations using a running 24-h mean. The smoothing eliminates noise.

\subsubsection{Model}

We used Environment Canada's Global/Regional Atmospheric Heavy Metals model (GRAHM; Dastoor et al., 2008; Dastoor and Larocque, 2004). GRAHM is an Eulerian model built on top of Environment Canada's Global Environmental Multiscale - Global Deterministic Prediction System (GEMGDPS) weather forecasting model (Côté et al., 1998a, b). Thus, it is a fully-coupled, online chemical transport model, where meteorological and mercury processes are fully integrated. The coupling of the processes is such that, at each timestep: 1) mercury emissions are added to the model concentrations, 2) the meteorological equations are integrated and the mercury species transported, and 3) mercury is deposited and processed chemically using information, including boundary layer stability and the behaviour of cloud water/ice, that is passed to the mercury module from the meteorological component of the model.

The GEM-GDPS is characterized by a semi-Lagrangian advection scheme to promote stability, and an implicit time scheme to control high frequency oscillations. We configured the model to use Interactions Soil-BiosphereAtmosphere (ISBA) land surface processes. The radiative transfer scheme, calculated every $1.5 \mathrm{~h}$, is based on Fouquart and Bonnel (1980) and Garand and Mailhot (1990). Stratiform precipitation is calculated by a Sundqvist-based scheme, while deep convective precipitation is calculated by a Kain-Fritsch scheme. Turbulent mixing of meteorologi- cal and mercury species in the boundary layer is based on prognostic turbulent kinetic energy. Cloud liquid water/ice content is a prognostic model variable.

GRAHM includes all chemical and physical processes related to mercury, namely emission, advection, chemical and physical transformations, and deposition. In polar regions, Atmospheric Mercury Depletion Events (AMDE) are simulated in springtime (Dastoor et al., 2008). Simulating AMDEs involves three distinct aspects: 1) the oxidation of mercury. This process includes simulating springtime "bromine explosions" (Lehrer et al., 2004), which are periodic, localized releases of oxidizing bromine species to the atmosphere; 2) the transportation of mercury-depleted air masses; and 3) air-snow exchanges of mercury, which are complex, heterogeneous processes, and are the focus of current work. It is likely that the relative importance of these three processes varies by location. The chemistry parameterization in GRAHM includes gas-phase oxidation of mercury by ozone and halogens, and aqueous-phase reduction of mercury by agents such as sulfur and through photochemistry. Wet and dry depositions are simulated using physical parameters calculated in the meteorological component of GRAHM. Dry deposition is based on the resistance approach, following Zhang et al. (2001, 2003).

We use the global anthropogenic mercury emission fields produced by Pacyna and co-workers valid in 2000 and 2005 (Pacyna et al., 2006, 2010). Non-anthropogenic emission estimates involve a high degree of uncertainty (Mason, 2009; Lohman et al., 2008). Our non-anthropogenic oceanic and terrestrial emissions of GEM are based on the global mercury budget of Mason (2009). Terrestrial non-anthropogenic emissions are divided into direct natural emissions, and 
reemissions of previously-deposited mercury. Direct natural emissions are distributed according to the natural geological enrichment of mercury. Reemissions are allocated according to the distribution of total deposition of mercury for historic years. The ratios of nonanthropogenic to anthropogenic emissions follow those of Gbor et al. (2007) over North America and those of Shetty et al. (2008) over East Asia. The seasonal and diurnal variations of terrestrial emissions and reemissions are parameterized as a function of leaf area index and incoming direct solar radiation, based on Shetty et al. (2008). Oceanic emissions are modulated by the sea surface temperature. The horizontal distribution of the model's total mercury emissions for the year 2000 are presented in Fig. 2. Values are shown for the year 2000 since almost half of our observations are from that year (Table 1). For the year 2000, our global anthropogenic and non-anthropogenic emissions amount to 2195 and $3308 \mathrm{Mg}$, respectively. This yields total global mercury emissions of $5503 \mathrm{Mg}$, which is in the range of uncertainty for these emissions (Mason, 2009).

We run GRAHM over a global domain using a $1^{\circ} \times 1^{\circ}$ horizontal resolution and a 30-min timestep. In order to match the operational model's vertical resolution, we use 28 vertical levels from the surface to $10 \mathrm{hPa}$ until November, 2006 and 58 levels thereafter. We reinitialize the GRAHM every $48 \mathrm{~h}$ using Canadian Meteorological Centre operational analyses, and produce a series of overlapping 60-h forecasts. The first 12 hours of each 60 -h forecast constitute a spinup period for the meteorology; the following $48 \mathrm{~h} \mathrm{sim}$ ulate mercury processes. Four years of successive forecasts (1996 through 1999), which used anthropogenic emissions valid in 2000, constituted the first spin-up period. They ensured a stable background load of mercury throughout the global atmosphere. The model was then run, using anthropogenic emissions valid in 2000, from 2000 through 2004. This series of forecasts provides some of the concentrations analysed in Section 3. A second spin-up period, which used anthropogenic emissions valid in 2005, extended from 2002 through 2004. The continuation of this series of simulations from 2005 through 2008 provided the remainder of the concentrations analysed in Sect. 3. Given significant uncertainties in emissions (Pacyna et al. 2006, 2010; Gbor et al., 2007; Shetty et al., 2008), and in mercury-related chemical processes (Lin et al., 2006), modeling the transport of mercury is a challenging task. GRAHM has been seen to perform well in past studies (Dastoor et al., 2008; Ryaboshapko et al., 2007a, b).

As per the observations, we lightly smooth the model values to eliminate noise. Since model values represent the average value for the entire grid cell, while observations are point values, a lesser 12-h running mean is applied to the model values, versus the $24-\mathrm{h}$ running mean applied to the observations.

For this study, we performed five simulations with GRAHM: with full global emissions (hereafter referred to as the base run) and with emissions from only Asia, North
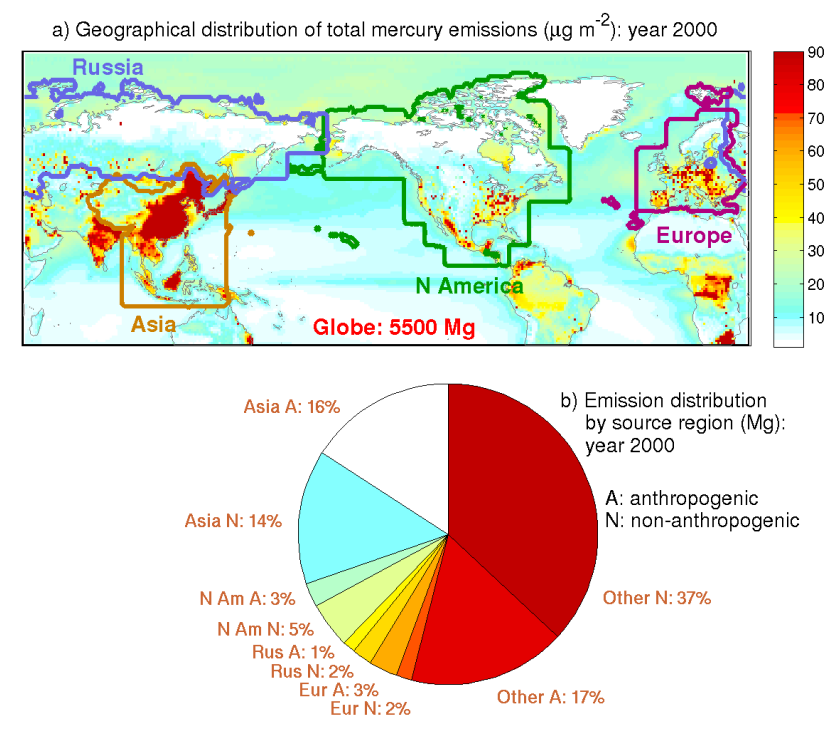

Fig. 2. Total mercury emissions for the study's four source regions and for the globe.

America, Russia or Europe. This enables us to estimate source attribution for mercury at a given site. The locations of the four source regions, along with the division of the total emissions into anthropogenic and non-anthropogenic components, are presented in Fig. 2. Our four source regions account for $46 \%$ of global emissions; Asian emissions alone account for $30 \%$ of the total. In Asia and Europe, anthropogenic emissions exceed non-anthropogenic emissions. The reverse is true in North America, Russia and the remainder of the globe. India, which is the focus of a separate ongoing study, is not included in the Asian source region; preliminary results indicate that, although India is a major source of mercury, the dynamics acting on mercury from this region yield low transport efficiencies in the Arctic and Canada.

\subsection{Calculations}

\subsubsection{Statistics}

The percent contribution of a source region's mercury to the base run's concentrations is calculated using Eq. (1):

Percent Contribution $=100 \cdot \frac{\sum_{\text {period }} \mathrm{TGM}_{\text {source }}}{\sum_{\text {period }} \mathrm{TGM}_{\text {base }}}$

where period represents the time period involved, and source and base represent the run using emissions from the specified source region only and the base run, respectively.

The correlation squared is calculated following the standard method. We correlate the base run's GEM/TGM values at a given atmospheric level to the source run's values at the same level. The correlation squared indicates the degree to 
which a source region's mercury determines the variability in the base run's concentrations.

The transport efficiency is calculated by dividing the mean concentration produced by a source region at a given site by that region's total annual mercury emissions. Since the calculation involves total annual emissions, seasonal variations in the transport efficiency reflect the seasonality of wind and precipitation fields. The transport efficiency is helpful for policy makers, as reducing emissions from source regions with large transport efficiencies will have the greatest impact at receptor sites.

\subsubsection{Long range transport events}

Long range transport is defined in this study as intercontinental transport. Therefore, Russian mercury transport events at Amderma, European events at Andoya and North American events at Canadian midlatitude and subarctic stations do not qualify as LRT events. However, North American events at Alert and European events at Ny-Ålesund do qualify as LRT events, since both stations are far from the emission sources.

LRT events are calculated using surface-level atmospheric mercury concentrations from five model simulations: the base run and the four simulations that use emissions from the individual source regions. At each station, the year's worth of concentrations depicted in Fig. 3 are used for the calculation. Thus, LRT events are always calculated over one calendar year, but the calendar year involved changes from station to station as indicated in Table 1 and Fig. 3.

The calculation of an LRT event is completely objective aside from the establishment of threshold values. At a given station, the base run's surface-level atmospheric concentrations are searched for local maxima. To be a candidate as an LRT event, a maximum must last for no more than six days, which is the synoptic time scale. Successive local maxima must be separated by at least $12 \mathrm{~h}$ to ensure the individuality of events. A local maximum must have a magnitude of at least 0.25 of the base run's standard deviation, calculated from all stations' data; using a common standard deviation ensures a constant minimum LRT event strength at all sites. The magnitude of the local maximum is defined as the difference of the concentration at the maximum and the greater concentration of the two flanking minima. Note that we do not require that the magnitude of the local maximum be at least the mean of the base run plus 0.25 of its standard deviation; a mercury-rich plume of air from a given source region that elevates the mercury concentration of the base run at a verification station is considered an LRT event even if the mean base run concentration is seasonally depressed, e.g. during late summer/early fall in midlatitudes or during spring in the Arctic. Note that a local maximum identified in the base run concentrations has not yet been defined as an LRT event; it is simply a candidate event. To be considered an actual LRT event, a collocated local maximum must be found in the concentrations from a source region.
Once a candidate LRT event has been located in the base run concentrations at a given station, the concentrations from each source region at that station are scanned for local maxima that occur within three days of the base run's maximum. The three-day window is permitted, as concentrations from a first source region may be declining at the onset of a second source region's LRT event; the LRT event is disguised until the 1st region's concentrations stabilize. A source region's local maximum must last for no more than six days and have a magnitude of at least 1.5 of the source region's standard deviation, calculated from all stations' data. As with the base run, we do not require that the local maximum be elevated above the source region's mean concentration at the verification station, so that LRT events can be identified regardless of the seasonality of the station's concentrations. The relative magnitude of the base run's maximum is permitted to be smaller than that of the source region's maximum, in view of the fact that the source region contributes only a fraction of the base run's concentration. North America's calculated standard deviation was halved, in consideration of the multitude of verification stations with local North American sources, which increase the standard deviation. Without this halving, it becomes much less likely that North American LRT events at arctic stations will be identified. A candidate LRT event is considered an actual event if no more than two source regions exhibit local maxima collocated with the base run's maximum. We permit two source regions to have simultaneous LRT events, as it is quite possible, for instance, that Asian mercury is transported to North America, and that subsequently Asian and North American mercury are transported together to a verification station. Similarly, mercuryrich plumes from Russia and Europe may easily be mixed and transported together. However, if more than two source regions exhibit local maxima collocated with the base run's maximum, it is considered that local dynamics are responsible for these maxima and that the candidate LRT event is not an actual event.

\section{Results}

\subsection{Individual stations}

\subsubsection{Time series of surface-level GEM/TGM}

The springtime period, including AMDEs, where GEM concentrations decrease dramatically (Steffen et al., 2005), is well reproduced by the base run at all six arctic stations (Fig. 3a-f). (The seasons are defined as follows: spring is March-May, summer June-August, autumn September to November, and winter December to February.) The base run is also successful at capturing background GEM concentrations at these stations, apart from at Alert during January and February. Note that extended periods of missing data at stations experiencing AMDEs can significantly affect the 

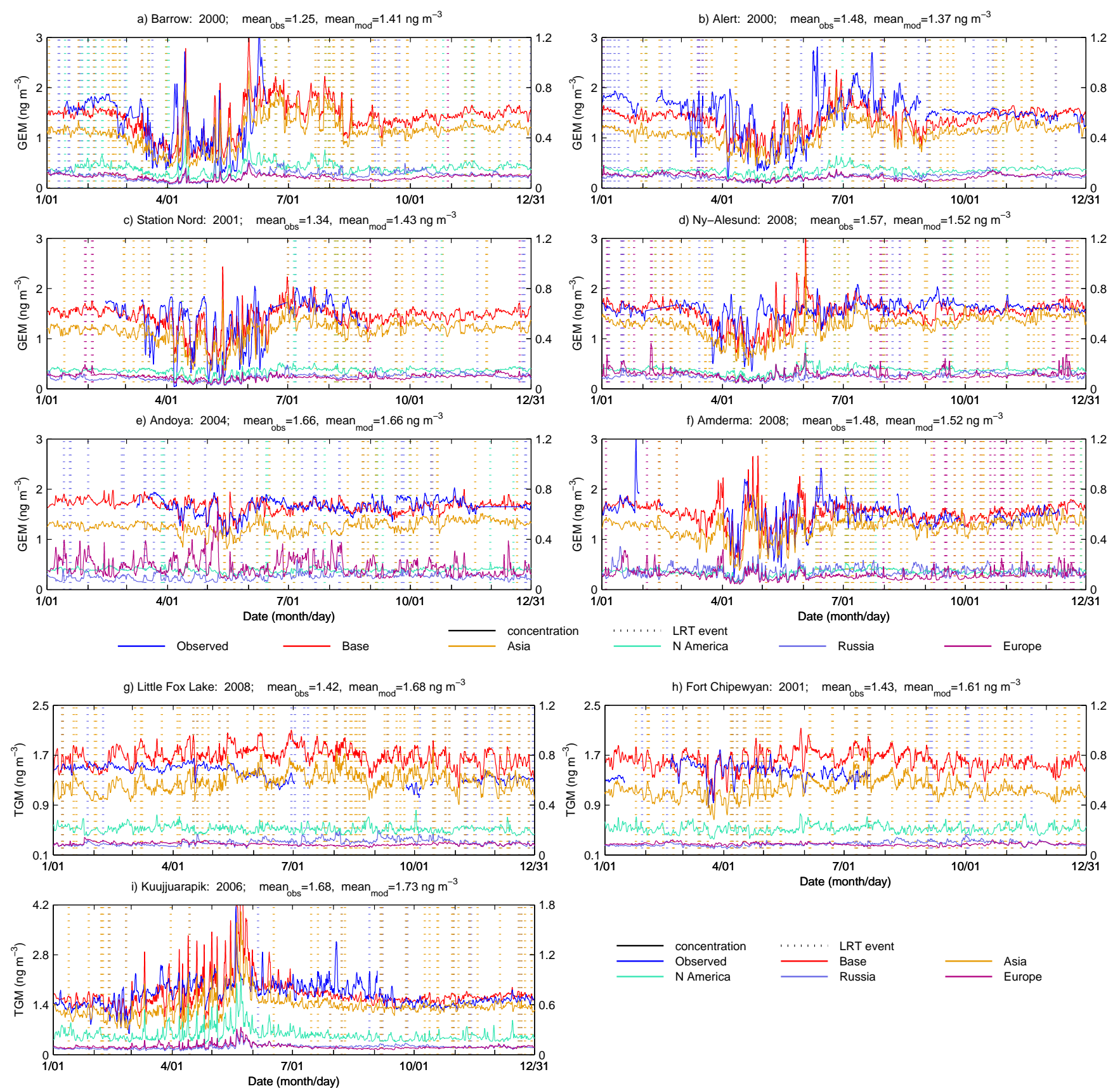

Fig. 3. Ambient surface-level GEM or TGM concentrations as observed at each verification station for the year indicated, and as simulated using emissions from the indicated source regions. The right hand axis pertains to observations and the base run. The left hand axis pertains to the simulations using emissions from only one of the four source regions. Note that axis limits are constant for panels $(\mathbf{a}-\mathbf{f})$ and $(\mathbf{j}-\mathbf{q})$, but that those of panel (i) differ from those of panels $(\mathbf{g}-\mathbf{h})$. Vertical dashed lines indicate LRT events. Stations from each station group are arranged from west to east.

calculated observed mean. This is demonstrated at Barrow, where a subjective examination indicates that the base run's and observed time series agree much more closely than the means, given in the panel title, would suggest. The observed mean is artificially depressed since observations at Barrow extend only from mid-January to mid-June; the very low springtime concentrations are included in the observed mean, but not the higher background concentrations of the rest of the year. The mean model GEM value over the six arctic stations is $1.50 \mathrm{ng}$ (standard $\mathrm{m})^{-3}$, hereafter $\mathrm{ng} \mathrm{m}^{-3}$, while the average observed mean is $1.55 \mathrm{ng} \mathrm{m}^{-3}$ at all arctic stations excluding Barrow and Station Nord. These two stations 

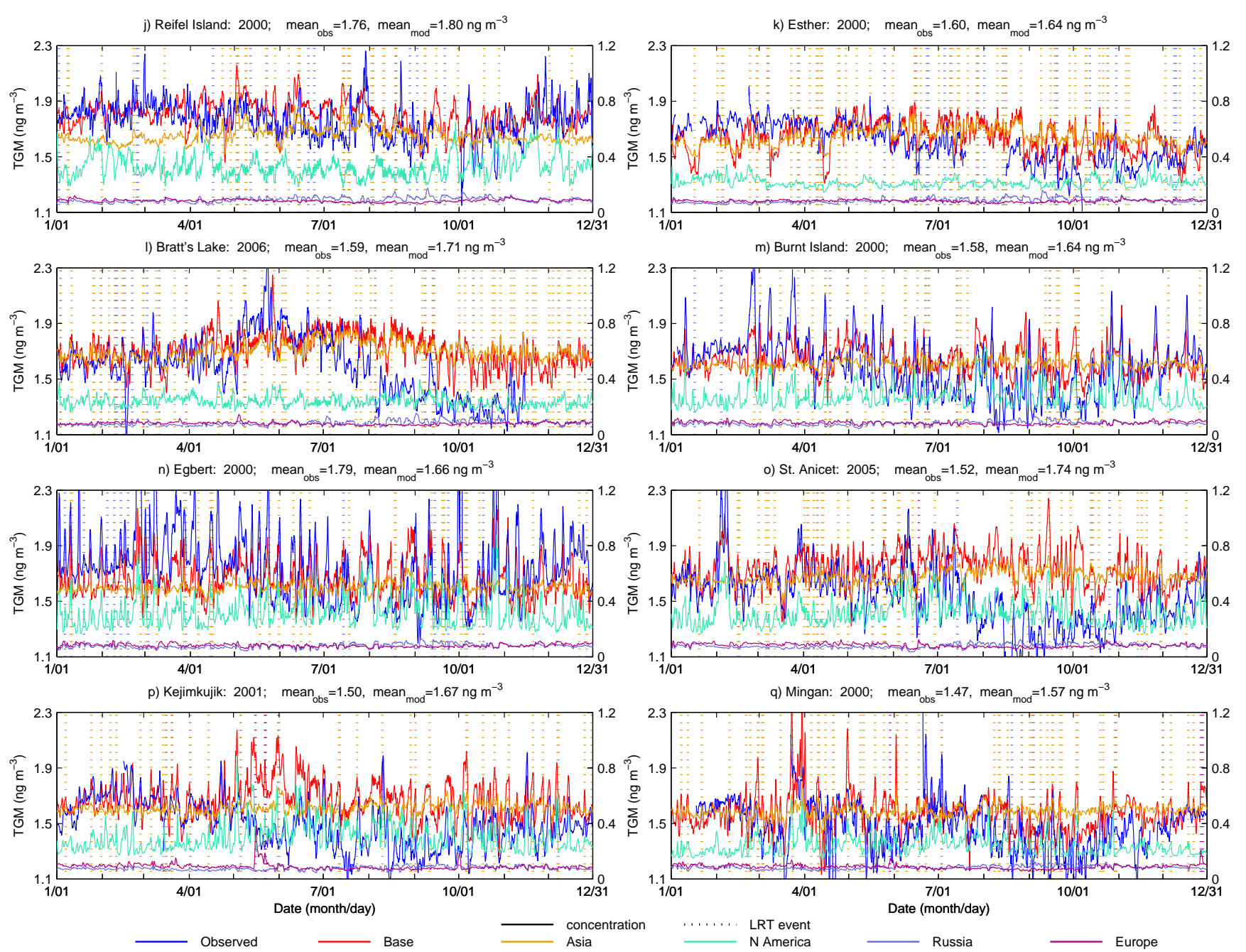

Fig. 3. Continued.

are excluded since they have extended periods with no data. Since concentrations at Andoya and Amderma are missing mainly during non-AMDE periods, the observed mean for the four Arctic stations would likely be increased if these data were included. The highest mean is at Andoya, which is not only fairly close to European emission sources but which also experiences weaker AMDEs (Berg et al., 2008); its mean is depressed less by these events. Non-AMDE variability in the base run and observations tends to match well, particularly at Ny-Ålesund, Andoya and Amderma, which are the three stations most affected by European emissions.

Asian GEM concentrations, which range from 0.4$0.6 \mathrm{ng} \mathrm{m}^{-3}$, are consistently considerably higher at the six arctic stations than those of the other three source regions, which are typically on the order of $0.1-0.2 \mathrm{ng} \mathrm{m}^{-3}$. Asian concentrations exhibit a summertime maximum. This maximum is strong at Barrow, Alert and Station Nord, weaker at Ny-Ålesund and Amderma, and absent at Andoya. North America and Russia produce noticeable summertime max- ima at Barrow, while only North America produces such a maximum at Alert. The proximity of Andoya to European emission sources yields elevated European concentrations of up to $0.4 \mathrm{ng} \mathrm{m}^{-3}$. Transport from Europe is so powerful at Andoya that the variability induced by the transport is able to mask any variability in the base run induced by springtime AMDE dynamics. The admirable reproduction by the base run of the springtime observations confirms the importance of the European emissions at this station.

Mean model base run concentrations at the three subarctic stations are higher than at the arctic stations (Fig. 3gi). The average model value at the subarctic stations is $1.67 \mathrm{ng} \mathrm{m}^{-3}$. This higher average reflects both the absence of AMDEs at two of the three subarctic stations, and also the mainly zonal nature of the transport of mercury emitted in the Northern Hemisphere, particularly in Asia (Fig. 8). The base run performs well at Kuujjuarapik, apart from its exaggeration of AMDE maxima and its lack of summertime variability. The problematic AMDE maxima reveal a 
weakness in the model's scheme to transfer mercury from the cryosphere to the atmosphere in the Hudson Bay area. As mentioned in Sect. 2.1.2, the complex, heterogeneous atmosphere/cryosphere mercury exchanges are currently an active area of research. The strong observed summertime variability at Kuujjuarapik is likely related to Kuujjuarapik's proximity to Hudson Bay; the model's lack of variability may be related to boundary layer chemistry and/or meteorological processes. The base run also fails to reproduce the summer/autumn decrease in concentrations observed at Little Fox Lake and Fort Chipewyan. However, the base run's performance in reproducing the variability in March and April at Fort Chipewyan is impressive. Excluding Fort Chipewyan, for which a substantial period of data is missing, the average of the observed concentrations at the subarctic stations is $1.55 \mathrm{n} \mathrm{m}^{-3}$. The inability of the model to capture the summer/autumn minimum at two of these three stations produces a model station group average higher than observed.

The model shows that Asian concentrations are higher at the subarctic stations, with background values ranging from 0.4 to $0.8 \mathrm{ng} \mathrm{m}^{-3}$., than at the arctic stations. Summertime maxima are exhibited at all three subarctic stations. North American values have also increased by approximately $0.05 \mathrm{ng} \mathrm{m}^{-3}$ from the arctic stations to a mean of $\approx 0.2 \mathrm{ng} \mathrm{m}^{-3}$ at the subarctic stations. Typical Russian and European values have decreased marginally. Russia exhibits late summer/early autumn maxima at the two westernmost subarctic stations.

The average base run mean over all the midlatitude stations is $1.68 \mathrm{ng} \mathrm{m}^{-3}$, which is the highest average of all three station groups. At the midlatitude stations, base run means are mainly higher than observed means (Fig. $3 j-q$ ); as at little Fox Lake and Fort Chipewyan, the model is unable to reproduce the seasonal decrease in concentrations, typically observed in late summer/early autumn. A similar minimum was documented by Weiss-Penzias et al. (2007) at Mount Bachelor Observatory, Oregon. The cause of this minimum is an active area of research. The current working hypothesis is that it is produced by chemical activity and not by changes in the emissions. Short-term variability at these stations is captured remarkably well by the model. The observed mean for the midlatitude stations is $1.60 \mathrm{ng} \mathrm{m}^{-3}$; the model's inability to capture the summer/autumn minimum leads to an overestimation of the station group average.

Asian concentrations range at the midlatitude stations from $0.5-0.7 \mathrm{ng} \mathrm{m}^{-3}$. This is higher than values seen at arctic stations and comparable to those at subarctic stations. Asian concentrations exhibit a distinct late spring/early summer maximum at the three westernmost stations and, in late summer/early fall, at St. Anicet. North American concentrations are significantly higher than at the more northerly stations, with values often at $0.4 \mathrm{ng} \mathrm{m}^{-3}$ and frequently surpassing $0.6 \mathrm{ng} \mathrm{m}^{-3}$. The great degree of variability in the North American concentrations indicates the close proximity of a local source. At Burnt Island, Egbert, and St. Anicet, the variabilities in the North American, base run and observed concentrations follow each other closely; it is a much easier task for the model to reproduce observed values when an important local source, well-represented in the emissions, dominates the behaviour of the observations. Russian and European concentrations are comparable to those at the subarctic stations. Russian concentrations exhibit a late summer/early autumn maximum, which is most noticeable in the westernmost stations. The onset of the Russian maximum starts earlier as one moves westwards and northwards.

Concerning model verification, we are able to state that, at a first level, the base model run was able to reproduce observed ambient GEM concentrations fairly well at each of our stations. We conclude that, although the meteorological and chemical processes active at the different sites likely vary, these processes are fundamentally identical; model threshold values have not been tuned nor have the parameterizations been modified in order to adapt the model to a given geographical region.

\subsubsection{Percent contribution}

Figure 4 indicates that the four source regions together contribute, on average, $56 \%$ of the base run's TGM/GEM concentrations. This significant elevation of the combined contribution over the $46 \%$ of total emissions produced by our four source regions (Fig. 2) likely reflects the proximity of the four source regions to our verification stations. It may also indicate that interhemispheric mixing is suboptimal. The lowest total contributions $(\sim 52 \%)$ are found in midlatitudes at $600 \mathrm{hPa}$ in autumn and winter, while the consistently highest contributions $(\sim 62 \%)$ are found from the surface up to $850 \mathrm{hPa}$, in the Arctic and subarctic during autumn; interhemispheric transport occurs most strongly at higher altitudes and lower latitudes and during autumn. (Note that we only consider levels up to $600 \mathrm{hPa}$, as Stohl (2006) demonstrated that only Asian air parcels up to $600 \mathrm{hPa}$ eventually reached the Arctic lower troposphere during winter. The levels 925,850 and $600 \mathrm{hPa}$ are just above the boundary layer, in the lower free troposphere, and in the mid troposphere, respectively.) One might expect our highest total contributions at high latitudes to occur during winter, not autumn; only high latitude pollution sources are expected to penetrate the polar dome during the coldest periods (Stohl, 2006; Law and Stohl, 2007). However, mercury's long lifetime permits it to travel polewards from lower latitudes, where it can mix with cold high-latitude air parcels over time before penetrating the polar dome. The stronger winds of winter (Fig. 8) are presumably able to transport the mercury more efficiently than during autumn, when the winds are weaker.

Asia contributes by far the greatest portion of atmospheric gaseous mercury (29-37\%) at all stations, seasons and levels considered. This is not unexpected, given that Asian emissions represent $30 \%$ of the total (Fig. 2). This Asian contribution corresponds well with previous estimates in the 

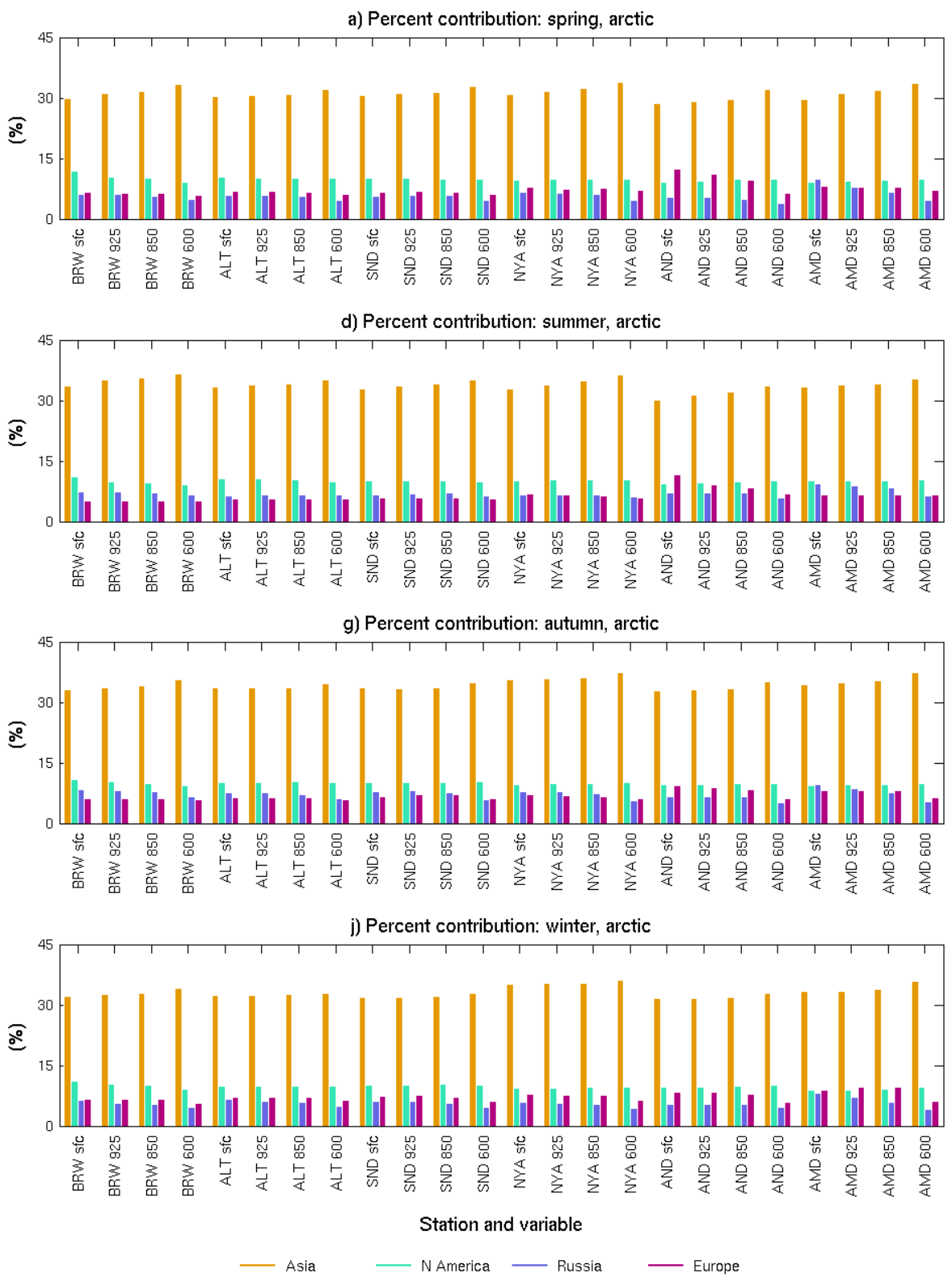

Fig. 4. Shown for the indicated station, level and season is each source region's percent contribution to the base run's concentrations. Table 1 identifies whether GEM or TGM contributions are calculated at the surface. GEM contributions are calculated at all stations at 925,850 and $600 \mathrm{hPa}$. Stations from each station group are arranged from west to east.

literature: Strode et al. (2008) show Asian surface-level mercury contributions over North America ranging from 31$36 \%$; Travnikov (2005) calculated that $33 \%$ of Arctic mercury deposition originated in Asia; since there are no local sources, deposition is proportional to the percent contribution of atmospheric mercury. Unexpectedly, our Asian contribution does not decrease from summer to winter at arctic stations; mercury's long lifetime is likely counteracting the traditional difficulty that pollution from warm source regions encounters when attempting to penetrate high latitudes in winter (Stohl, 2006; Law and Stohl, 2007).
Strode et al. (2008) calculated a surface-level contribution from North American sources, averaged over the entire USA, of $20 \%$. The eight Canadian midlatitude stations are characterized by an average of $14 \%$; our lower average reflects the fact that there are more mercury emissions in the USA than in Canada (Fig. 2).

Our European percent contributions range between $4.5 \%$ and $7.5 \%$, with the higher values in the Arctic. Except at Andoya, for which Europe is a local source, contributions decrease only minimally with height. This contradicts the statement by Stohl et al. (2002) that, because of less vigorous 

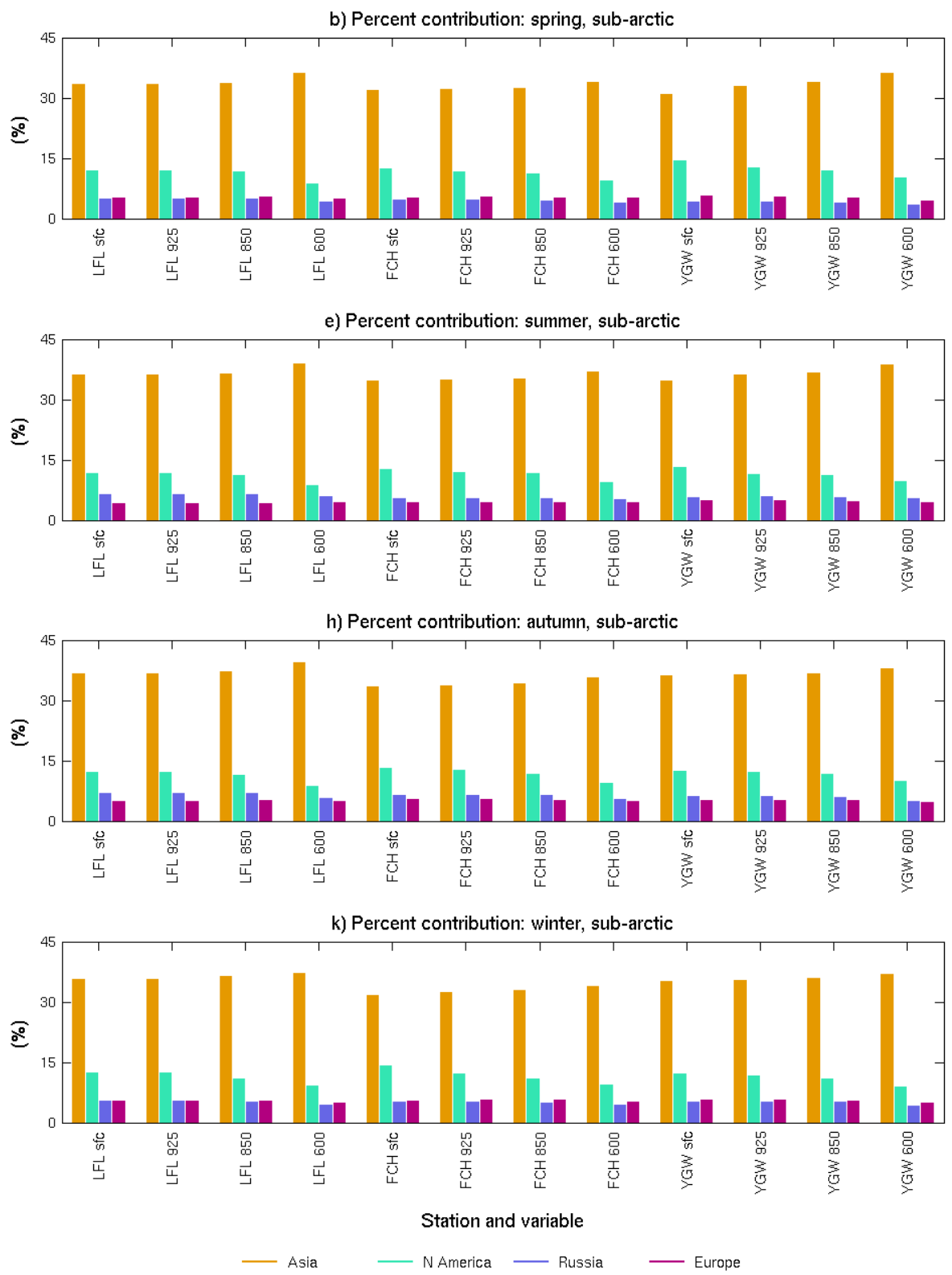

Fig. 4. Continued.

convection and less frequent cyclogenesis, European emissions tend to remain in the lower troposphere. This apparent contradiction is possibly resolved by the long lifetime of mercury; their simulation, which did not involve mercury, lasted only one year, while we find a spinup period of at least three years necessary to reach a balanced global distribution of mercury. Our results also disagree with Travnikov (2005), who estimated that Europe contributes $22 \%$ of the mercury deposition in the Arctic. Given the distance between European emissions and the Arctic, this result suggests that Europe also contributed $22 \%$ of the ambient mercury. This discrepancy is likely a result of differences in the emission fields used. Travnikov (2005) used anthropogenic emissions from 1995, where the European contribution is estimated at 250 tonnes by Pacyna et al. (2003). We used emissions from either 2000 or 2005. By 2000, European emissions were estimated to have dropped by some $30 \%$ to 175 tonnes (Pacyna et al., 2006). By 2005, these emissions were estimated to have dropped a further 20\% to 140 tonnes (Pacyna et al., 2010).

Eleftheriadis et al. (2009) determined that black carbon concentrations at $\mathrm{Ny}$-Ålesund originated mainly in Russia. This disagrees with our finding that Russia contributes only a small percentage of the ambient mercury at Ny-Ålesund. 

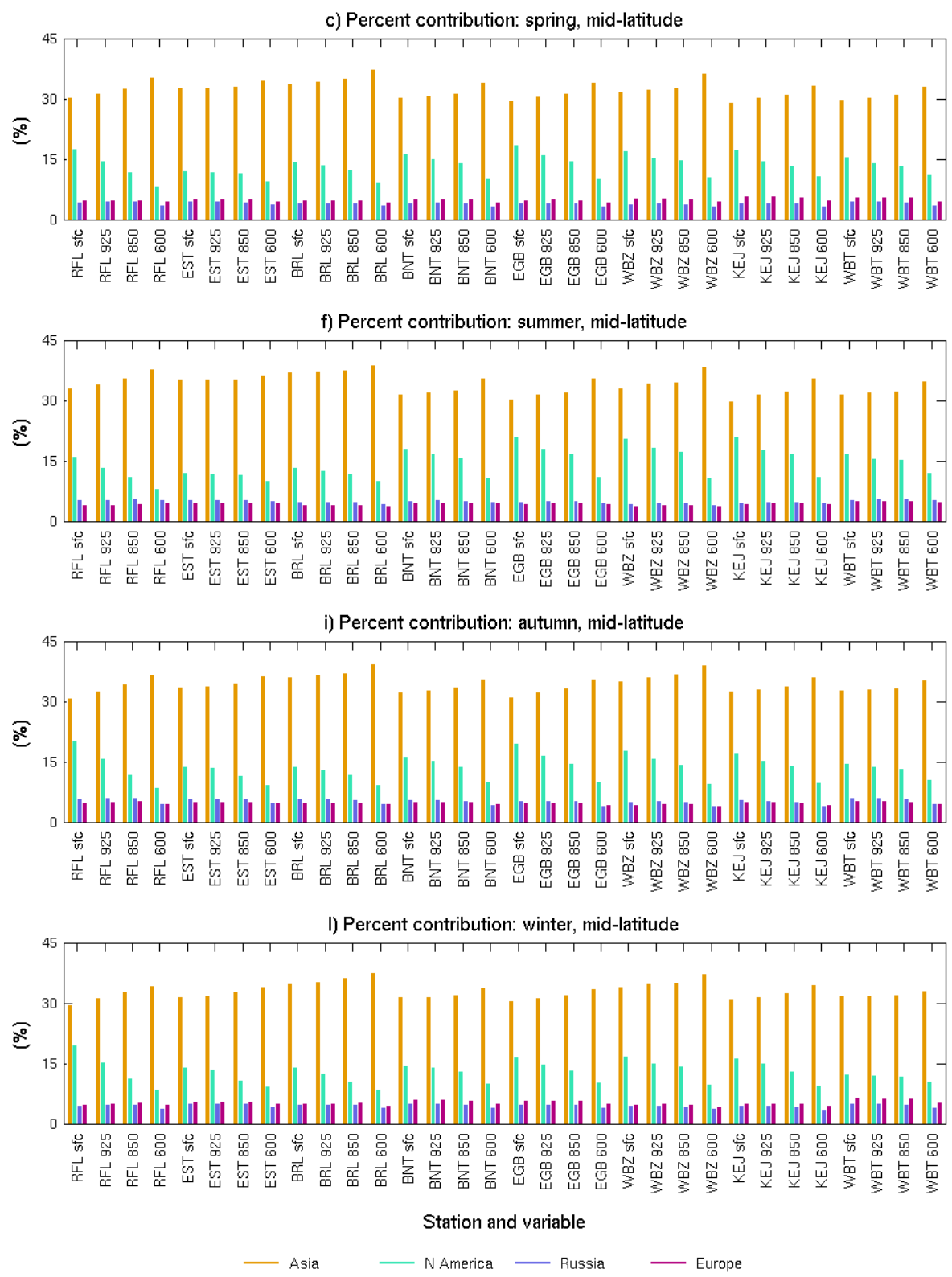

Fig. 4. Continued.

The difference in lifetimes is likely responsible for this discrepancy.

In general, the Asian contribution increases with altitude in all seasons at all stations. This behaviour, which is the signature of a non-local mercury source, is most pronounced at midlatitude stations, where North America is a local source. Conversely, the signature of a local source is the decrease with altitude of the source region's contribution. North America is a local source at all subarctic and midlatitude stations in all seasons. The importance of North America as a local source diminishes rapidly with latitude. Thus, the noticeable Asian increase in percent contribution with eleva- tion at the midlatitude stations is simply a consequence of the strength of North America as a local source at these stations. Russia is a local source at Amderma, and Europe at Andoya.

\subsubsection{Correlation squared}

Concentrations from all source regions are highly correlated in spring with the base run's surface-level concentrations at subarctic Kuujjuarapik and at all arctic stations, except at Andoya. This reflects the dominance of AMDE dynamics in determining the variability at these stations during this season (Fig. 5). At Andoya, the competition between the weak 

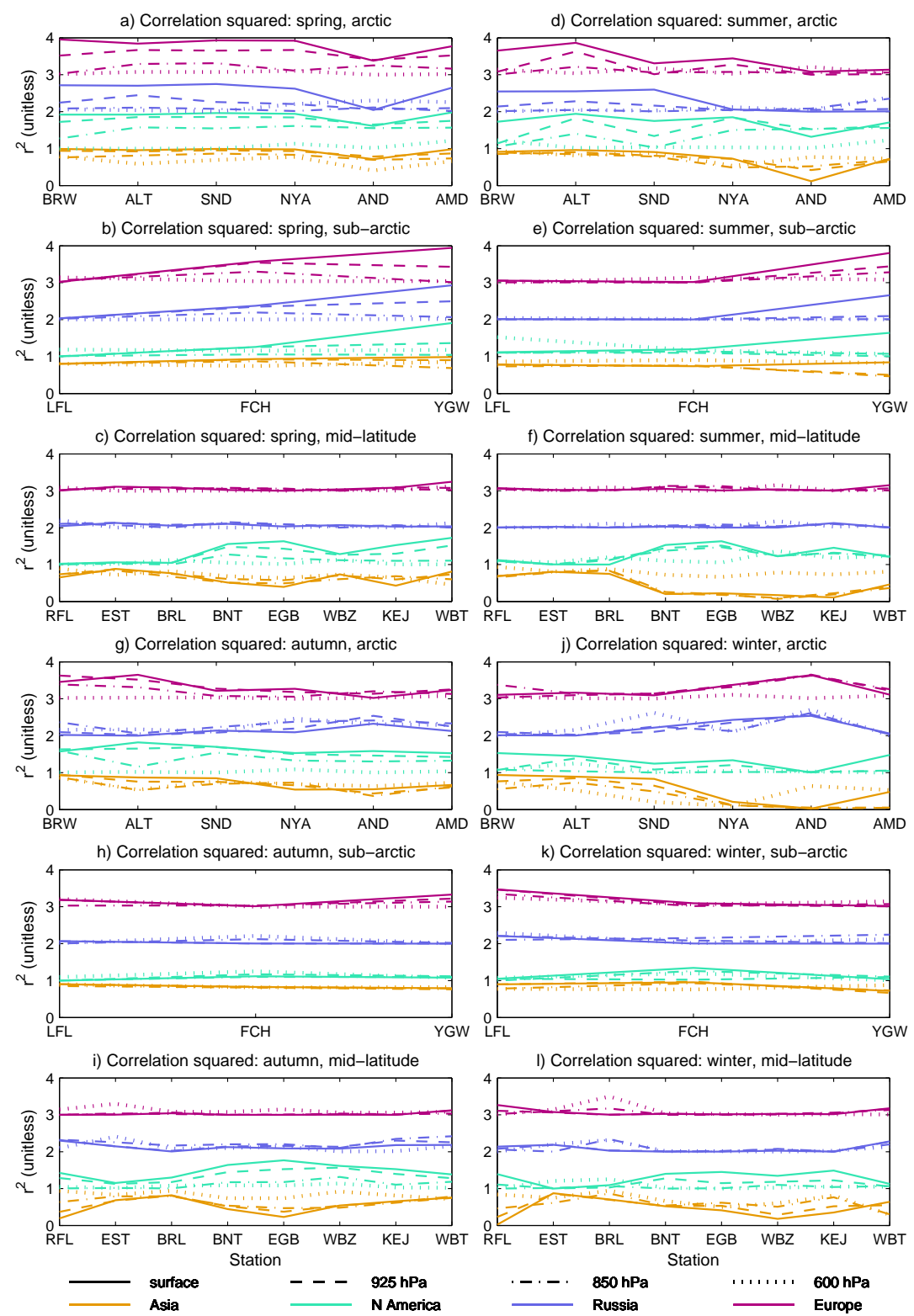

Fig. 5. Shown for each source region at the indicated station, level and season is the correlation squared between the base run's mercury concentrations and the concentrations simulated using the specified source region's emissions alone. Values from North America, Russia and Europe are increased successively by unity to promote readability. Table 1 identifies whether GEM or TGM correlations are calculated at the surface. GEM correlations are calculated at all stations at 925, 850 and $600 \mathrm{hPa}$. Stations from each station group are arranged from west to east.

AMDEs (Berg et al., 2008) and the strong transport from Europe (Fig. 3) to dominate the base run's variability explains the reduced springtime surface-level correlations for all source regions' concentrations.

In all other situations, Asia tends to dominate the base run's variability. Asian correlations are frequently valued near unity at all levels. This suggests either that mercury from Asia moves in a deep wave through the atmosphere, or that, regardless of the transport level, Asian mercury-rich plumes are characterized by sufficiently high concentrations that they are able to dominate individually the base run's variability. Both behaviours have been documented in the literature: Jaffe et al. (2005) noted the coherence with altitude of an air mass causing an Asian LRT event in Oregon; Radke et al. (2007) observed Asian mercury being transported in individual mercury-rich layers. The strong Asian correlations in the Arctic break down in winter, when it is most difficult for mercury from this warm-temperature source to penetrate the polar dome (Stohl, 2006; Law and Stohl, 2007). At both arctic and subarctic stations, Asian correlations tend to decrease 
as one moves eastwards, presumably as a result of increased mixing of air parcels. At midlatitude stations, Asian correlations exhibit a distinctive wave pattern, which is mirrored by North American correlations. This pattern is generated by the behaviour of North American, not Asian, mercury: near a local source, variability in the base run is dominated by North America, which reduces the Asian influence. Away from these sources, the North American influence wanes, and Asia returns to its typically dominant behaviour. The similar correlations calculated for Burnt Island and Egbert are to be expected, given the strong correlation found between the mercury concentrations of these two stations by Kim et al. (2005). The midlatitude correlations suggest that Reifel Island, Burnt Island, Egbert, St. Anicet and Kejimkujik are all affected by a local source. Esther, Bratt's lake and Mingan are much less affected by local sources.

Strode et al. (2008) calculated that Asian mercury explains $42 \%$ of the springtime variability and $57 \%$ of the annual variability at Mount Bachelor Observatory, Oregon. At Reifel Island, which is geographically our closest station, Asian mercury explains $65 \%$ and $69 \%$ of the surface-level variability in spring and summer, respectively, and $19 \%$ and $3 \%$ of the surface-level variability in autumn and winter, respectively. This contrary behaviour is likely explained by differences in the two sites' locations: Reifel Island is at sea level right next to the ocean and near Vancouver, while Mount Bachelor Observatory is $180 \mathrm{~km}$ inland at an altitude of $2.7 \mathrm{~km}$, and mostly experiences free tropospheric air (Jaffe et al., 2005). Reduced Asian correlations indicate the dominance of a local source at Reifel Island in autumn and winter, and at Mount Bachelor in spring. Weiss-Penzias et al. (2006, 2007) documented springtime transport events at Mount Bachelor Observatory that were attributed to local mercury sources.

\subsubsection{Transport efficiency}

Although, on average, Asia contributes the most mercury and explains most of the base run's variability at all 17 stations, Asia's transport efficiency is almost always less than that of North America and often less than that of Russia (Fig. 6), particularly during summer and autumn. Given that Asian and North American emissions are at comparable latitudes, the lower Asian efficiencies at the arctic stations might be considered somewhat surprising. Similarly, given that Russian emission sources are farther from the midlatitude stations than are the Asian sources, it appears to be somewhat surprising that Russian and Asian transport efficiencies are comparable at these stations. The difference is likely explained by Fig. 9, which demonstrates that the maximum concentrations due to Asian emissions tend to be located higher in the troposphere than those due to North American or Russian emissions; the greatest concentrations from Asian emissions, which would produce the strongest transport efficiencies, are often above our top level of $600 \mathrm{hPa}$. This supposition is supported by the tendency of Asian efficiencies to increase strongly with altitude. At subarctic and midlatitude stations, European efficiencies are always smaller than Asian efficiencies. In the Arctic, European efficiencies are smaller than Asian efficiencies most often in summer and autumn and least often in winter and spring.

The importance of Russian efficiencies in the Arctic in all seasons, and its dominance in summer and autumn, is to be expected, given that it is relatively close to the Arctic and is a high latitude source, so that its mercury is more easily able to penetrate the polar dome (Stohl, 2006; Law and Stohl, 2007). This Russian importance is supported by Stohl (2006). However, the lesser importance of our European transport efficiencies in the Arctic do not agree with most published results. During his study on aerosols, Stohl (2006), who calculated efficiencies for air parcels at or below $500 \mathrm{~m}$ that have resided 5 days or more north of $70^{\circ} \mathrm{N}$ during winter, placed European efficiencies second to Russian efficiencies, followed by North America and Asia. Shindell et al. (2008), who did not have a Russian source region, found the same surface-level wintertime efficiency rankings as Stohl (2006) otherwise for a carbon monoxide-like tracer. Considering only wintertime surface-level transport efficiencies at Alert, Station Nord and Ny-Ålesund, which are well north of $70^{\circ} \mathrm{N}$, we agree that Russia dominates, but rank North America unexpectedly second, and Europe on the same order of importance as Asia. The reason for this disagreement is likely the long lifetime of mercury. Stohl (2006) used back trajectories of no more than 30 days, while the tracers of Shindell et al. (2008) had a 50-day lifetime. It is not unreasonable to think that mercury that ends up at the surface in the Arctic after being transported for six month to two years may well originate in different regions than particles that have travelled for a fraction of that time. In fact, some sensitivities calculated by Stohl (2006) yielded minimal differences between Europe and North America. Furthermore, Lin et al. (2001) found that Europe was a less important source of mercury for Alert during winter than Russia or North America. Lin et al. (2001) also found evidence that, even during winter, Asian mercury was reaching Alert.

In the Arctic, Russian efficiencies often maximize at $850 \mathrm{hPa}$. However, Russian efficiencies at Amderma and, to a lesser extent, at Andoya, tend to decrease with altitude. This tendency to decrease with altitude is also observed at all arctic stations during winter. Similarly, European wintertime transport efficiencies for the Arctic tend to be smallest at $600 \mathrm{hPa}$, particularly at nearby Ny-Ålesund, Andoya and Amderma. This agrees with findings from Stohl (2006) and Shindell et al. (2008). Our wintertime Asian efficiencies in the Arctic tend to increase with altitude, but often only minimally. Stohl (2006) and Shindell et al. (2008) both found an increase with altitude. The tendency for our North American transport efficiencies at arctic stations to increase with altitude during autumn and winter is also confirmed by Shindell et al. (2008). 

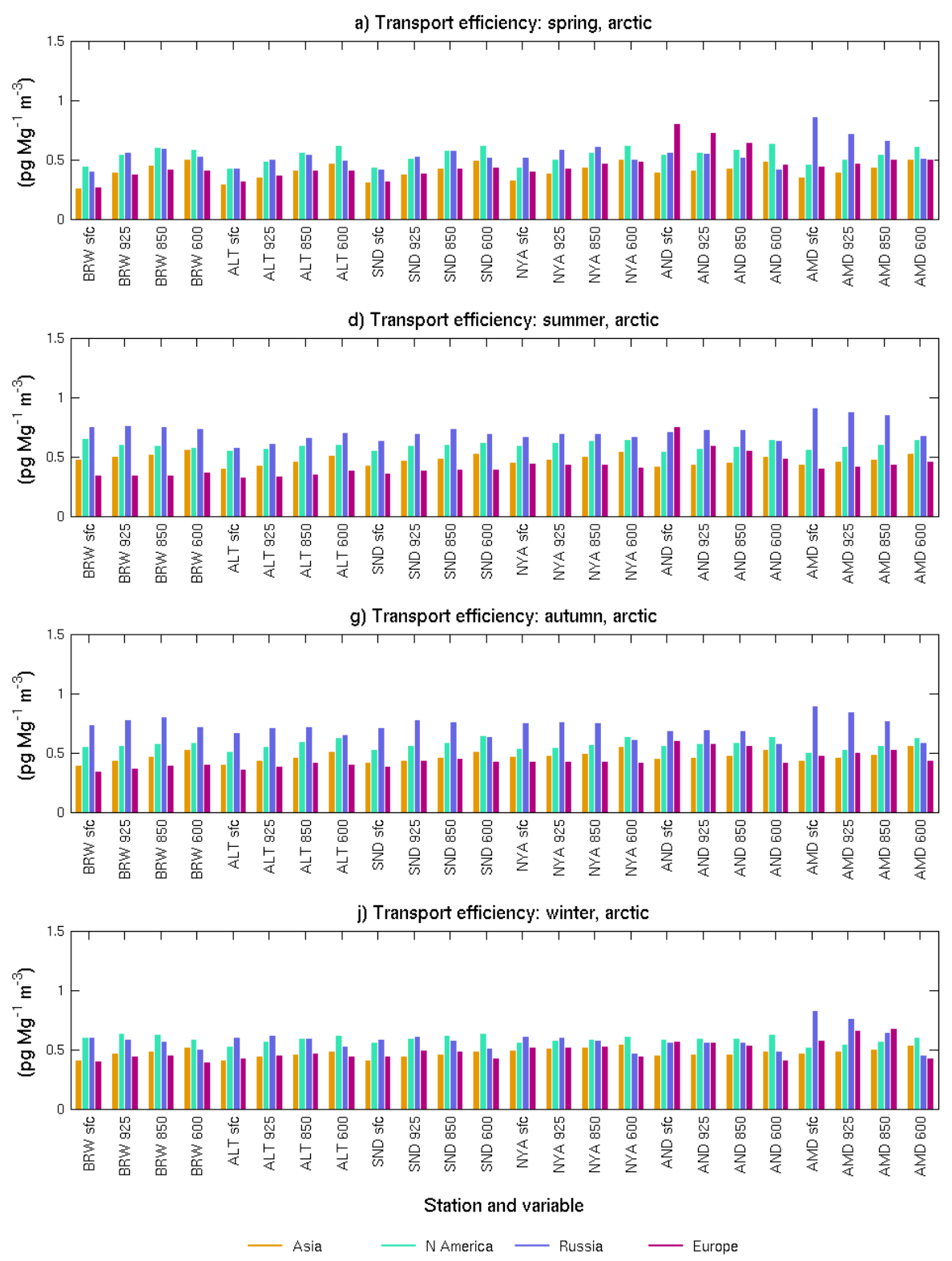

Fig. 6. Shown for the indicated station, level and season is each source region's transport efficiency. Table 1 identifies whether GEM or TGM efficiencies are calculated at the surface. GEM efficiencies are calculated at all stations at 925, 850 and $600 \mathrm{hPa}$. Stations from each station group are arranged from west to east.

North American efficiencies tend to dominate at subarctic stations and dominate overwhelmingly at midlatitude stations. This is to be expected, given the proximity to emission sources.

\subsubsection{LRT events}

The six arctic stations together recorded 470 LRT events per year, averaging 78 events per station (Table 2). The three subarctic stations also averaged 78 events per station per year, recording 234 events in all. 442 events per year were recorded between the eight midlatitude stations, yielding an average of 55 events per station. The distribution of events within a station group is discussed below.

Asia was responsible for the majority of all LRT events, producing $43 \%, 67 \%$ and $75 \%$ of the events at the arctic, subarctic and midlatitude stations, respectively. LRT events are only defined for North America at arctic stations (see Sect. 2.3.2). At these stations, North America contributed $16 \%$ of all events. The greatest share of Russian LRT events was at subarctic stations (33\%), followed by arctic (27\%) then midlatitude stations (23\%). Europe's LRT events 

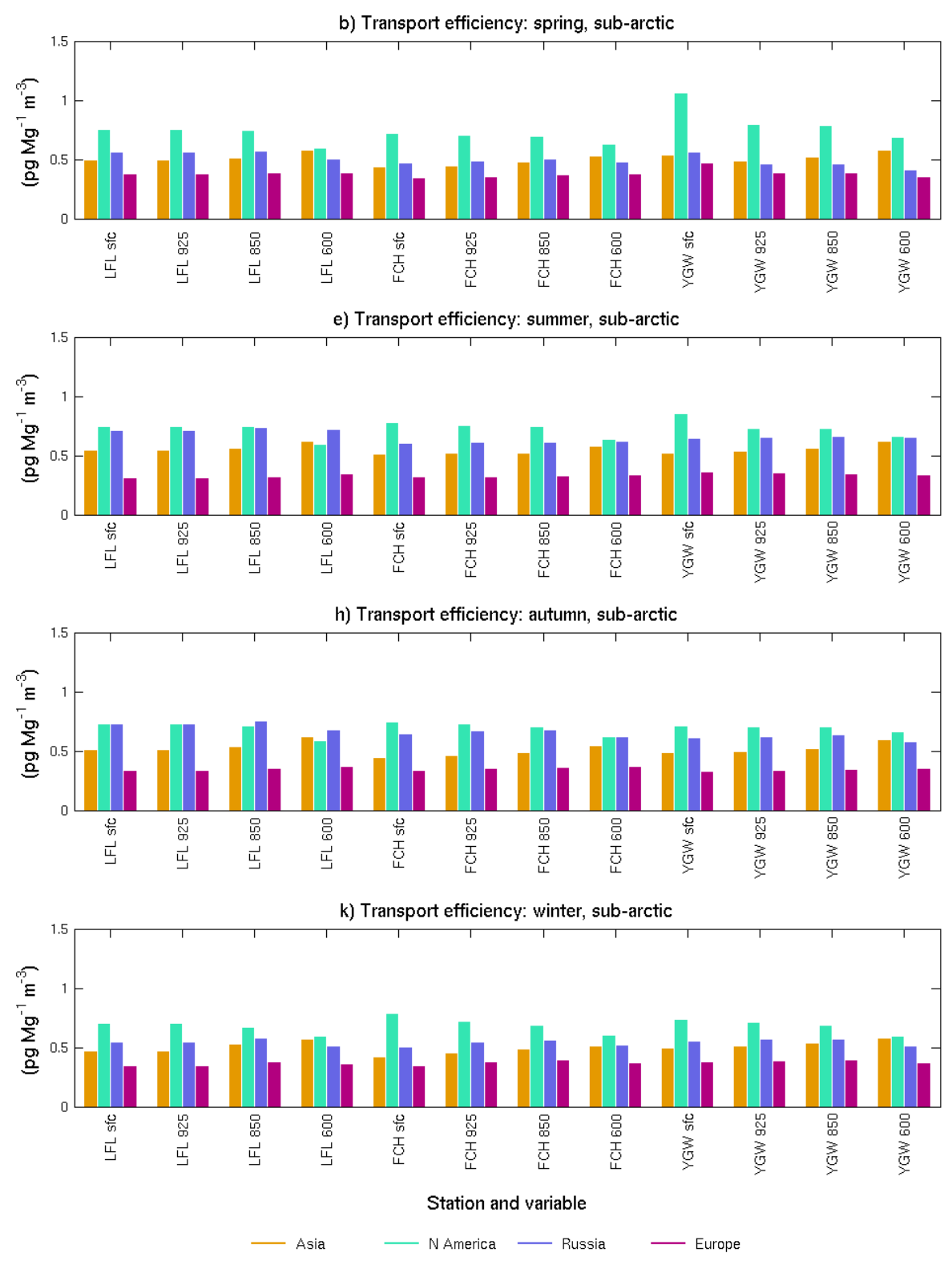

Fig. 6. Continued.

occurred almost exclusively in the Arctic (14\%), with none at any subarctic station, and only $2 \%$ at midlatitude stations.

In the Arctic, Asian and North American LRT events occurred preferentially in summer, while both Russian and European events occurred preferentially in winter (Fig. 3, Table 2). Stohl (2006) found that the mean Arctic age of air increased from January to July at all our verification stations. This would lead us to expect fewer LRT events in summer than winter; the Asian and North American behaviour is unexpected. However, our verification stations are located in high gradient areas of the mean Arctic age of air fields calculated by Stohl (2006); these areas may be less accurate. Moreover, the overall age of air was found to be shorter in
January on the European/Russian side of the Arctic than on the North American side, indicating that European and Russian air masses penetrate nearby Arctic regions in wintertime more easily than Asian or North American air masses. This agrees with our Russian/European winter LRT preference versus our Asian/North American summer preference. Lin et al.'s (2001) lack of evidence of summertime mercury LRT events at Alert may be an artifact of their 10-day back trajectories; weak summer winds transport air masses slowly. The fewest arctic events occur in spring for all source regions, presumably because local AMDE dynamics mask the less vigorous variations in model concentrations caused by LRT events. This masking of springtime mercury LRT events 

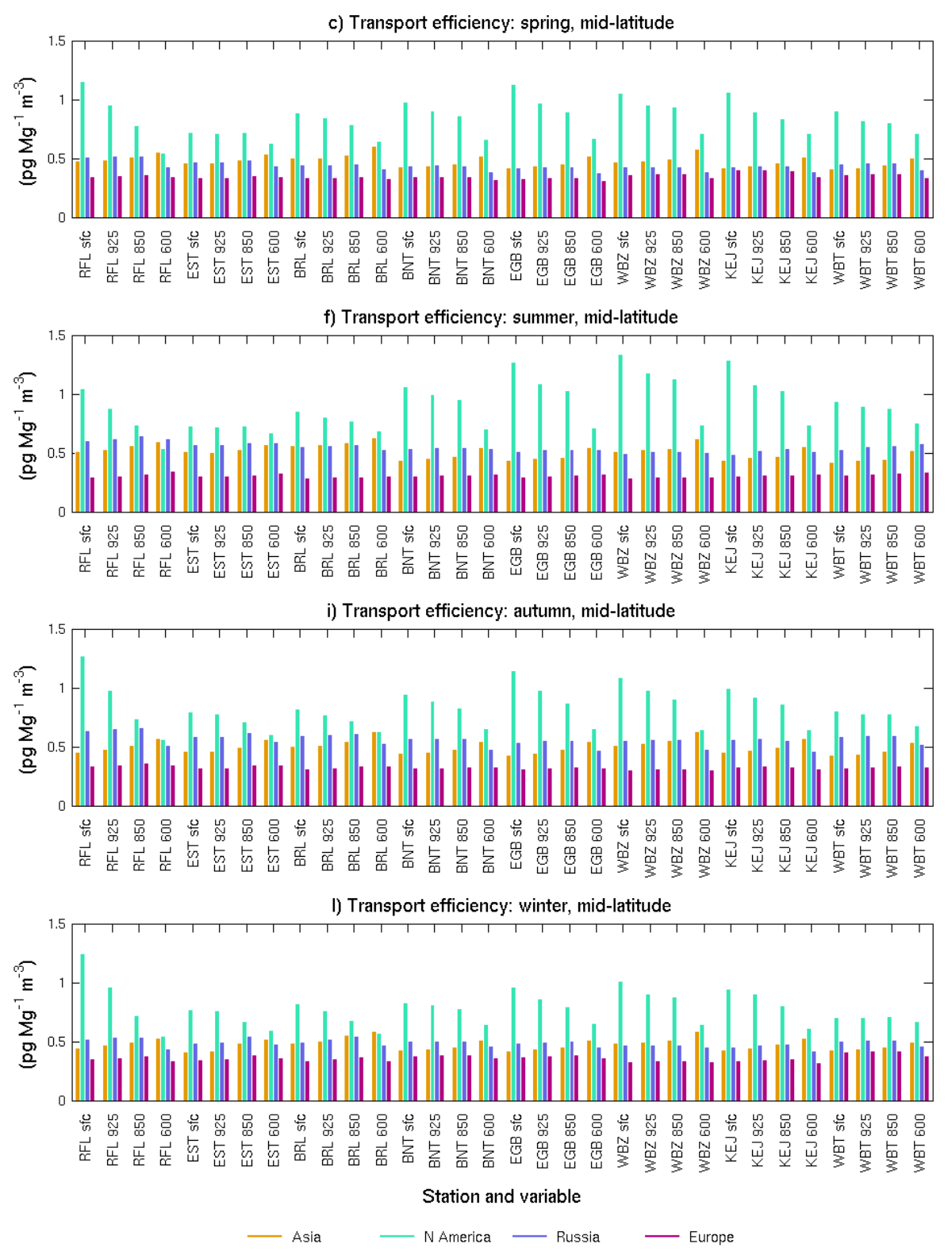

Fig. 6. Continued.

by AMDEs is confirmed by Lin et al. (2001). In contrast, Warneke et al. (2009) found spring to be an active LRT season in the Arctic for aerosols, which do not participate in AMDEs, finding 50 plumes during six flights in the vicinity of Barrow. Biomass burning in Russia was identified as the source of these plumes.

Subarctic LRT events, which are produced only by Asia and Russia, occur most often in autumn, and least often in spring. The masking effect of Kuujjuarapik's AMDEs will have lowered the spring LRT count for this entire station group. In the midlatitude stations, where there are no AMDEs, Russia was most active in summer, but both Asia and Europe generated their greatest number of events in spring. This springtime preference for the trans-Pacific transport of Asian pollution was confirmed by Wang et al. (2009) and Liang et al. (2004).

Considering individual stations, Asia generates the most LRT events at the three lower latitude arctic stations (Barrow, Amderma and Ny-Ålesund) and at the two westernmost stations of the midlatitude group (Fig. 3, Table 3). Reifel Island's unexpectedly low number of Asian LRT events is possibly due to its sea-level elevation. It is also likely that the local source that is active at Reifel Island during autumn and winter (Sect. 3.1.3) masks LRT events from all sources, including Asia. Asian carbon monoxide LRT events are known to reach eastern North America, despite the effects of mixing 
Table 2. Distribution of LRT events by season.

\begin{tabular}{lrrrrrr}
\hline Source region & Spring & Summer & Autumn & Winter & Total & \% of total \\
\hline \multicolumn{7}{c}{ Arctic stations } \\
\hline Asia & 33 & 70 & 64 & 34 & 201 & $43 \%$ \\
North America & 12 & 27 & 20 & 18 & 77 & $16 \%$ \\
Russia & 26 & 35 & 26 & 39 & 126 & $27 \%$ \\
Europe & 5 & 9 & 21 & 31 & 66 & $14 \%$ \\
All 4 regions & 76 & 141 & 131 & 122 & 470 & $100 \%$ \\
\hline & \multicolumn{7}{c}{ Sub-arctic stations } & & & \\
\hline Asia & 34 & 37 & 48 & 38 & 157 & $33 \%$ \\
North America & N/A & N/A & N/A & N/A & N/A & N/A \\
Russia & 13 & 17 & 32 & 15 & 77 & $16 \%$ \\
Europe & 0 & 0 & 0 & 0 & 0 & $0 \%$ \\
All 4 regions & 47 & 54 & 80 & 53 & 234 & $50 \%$ \\
\hline & \multicolumn{7}{c}{ Midlatitude stations } & & & \\
\hline Asia & 97 & 78 & 88 & 70 & 333 & $71 \%$ \\
North America & N/A & N/A & N/A & N/A & N/A & N/A \\
Russia & 24 & 28 & 25 & 24 & 101 & $21 \%$ \\
Europe & 5 & 1 & 0 & 2 & 8 & $2 \%$ \\
All 4 regions & 126 & 107 & 113 & 96 & 442 & $94 \%$ \\
\hline
\end{tabular}

and dilution (Ding et al., 2009). Nonetheless, our high frequency of Asian LRT events at east coast Mingan seems somewhat surprising. However, this frequency becomes less surprising when one considers that active local sources at Burnt Island and Egbert (Sect. 3.1.3) probably mask LRT events at these stations. North American LRT events occurred most and least frequently at Barrow and Alert, respectively. This distribution is fully explained by Fig. 8, which will be discussed in Sect. 3.2.1. Alert, on the other hand, received the most Russian LRT events of any arctic station. At subarctic and midlatitude stations, Russian LRT events occurred preferentially at western stations. The occurrence of Russian LRT events in northwestern North America is also documented by Bertschi and Jaffe (2005). Not surprisingly, European LRT events are more frequent at nearby Amderma and Ny-Ålesund than the other arctic stations. On the other hand, the fact that midlatitude Kejimkujik and Mingan both experience European LRT events is unexpected. These events will also be explained in Sect. 3.2.1.

Comparing the LRT statistics at neighbouring arctic stations (Table 3), Ny-Ålesund and Amderma recorded almost identical numbers of events, despite the distance separating them. This suggests that they are governed by similar dynamics and transport pathways. Similarly, Station Nord, which is far closer to Ny-Ålesund than Amderma, experienced similar numbers of LRT events as Ny-Ålesund from Asia, North America and Russia. However, the number of recorded European events at these two stations differs significantly. Alert is no farther from Station Nord than Ny-Ålesund. How- ever, while Alert recorded a comparable number of European events as Station Nord, it recorded almost twice as many Russian events and just over half as many North American events; the dynamics governing mercury concentrations at these two stations are very different. Alert also behaves very differently than Barrow. Similarly, Andoya and Ny-Ålesund, despite their proximity, behave quite differently. Thus, one cannot decide that dynamics and transport pathways affecting two separate locations will be similar or dissimilar based on proximity alone.

Figure 7 presents a visualization of the annual distribution of LRT events generated at the 17 verification stations (Table 3). To generate this figure, we considered the number of events recorded at each station, regardless of transect, from each source region. From these 17 values per source region, we calculated the median, 75 th percentile and maximum values of LRT events recorded per station. The calculated values are presented in Table 4 . In this figure, stations receiving the maximum number of LRT events from a given source region recorded at any station are assigned a bold-font capital letter indicating the source region. Stations receiving at least the 75 th percentile number of events from a given source region are assigned a capital letter indicating the source region. Finally, stations receiving at least the median but not as many as the 75th percentile number of events from a given region are assigned a small-case letter indicating the source region. Plotting these statistics indicates preferred routes travelled by mercury-rich plumes from the four source regions. Thus, plumes from Asia travel primarily 
Table 3. Distribution of LRT events by station.

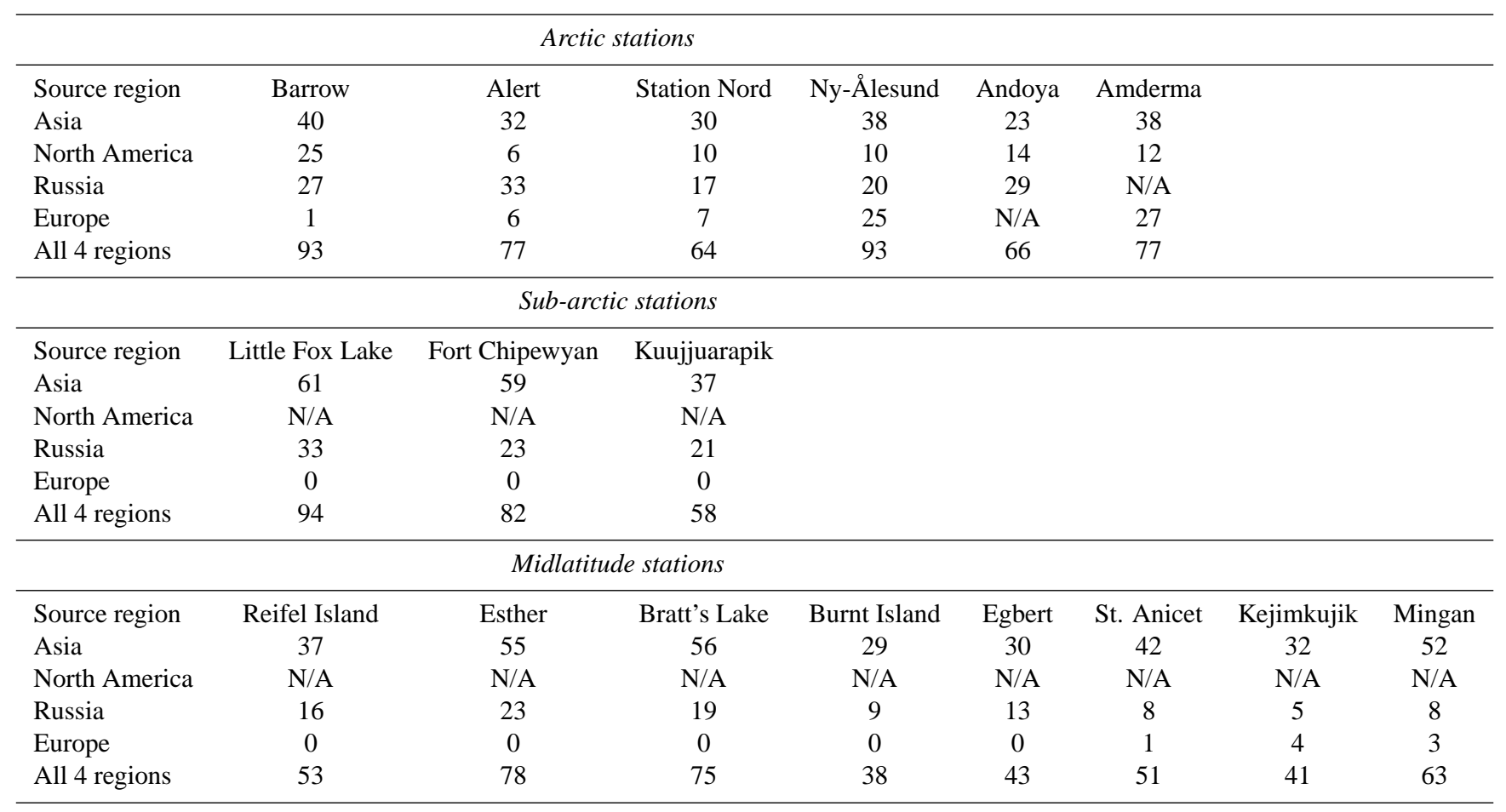

zonally, with stations in western North America recording the most LRT events. A secondary route for Asian plumes is polewards to the Arctic over the former USSR. North American LRT plumes travel predominantly northwards to Barrow, or zonally to Andoya and Amderma. Russian plumes travel either zonally into North America, directly across the Arctic Ocean to Alert, or westwards to Andoya. European plumes are recorded primarily in the Arctic, with a secondary route across the Atlantic to the stations of eastern Canada.

Interestingly, transport efficiencies and percent contributions do not always support the behaviour apparent in the LRT event statistics. For instance, Russian surface-level contributions and efficiencies at Alert and Station Nord are almost identical, despite the fact that Alert recorded nearly double the number of Russian LRT events. An LRT event consists of a high mercury concentration pulse, preceded and followed by lower concentration air masses; a direct route from the source to the station is required. In contrast, the efficiency and contribution are based on the amount of mercury that has reached a station over an entire season; indirect routes, involving considerable mixing, that deliver smaller amounts of mercury over longer periods are possible. Thus, there is no reason why the LRT statistics should be supported by the transport efficiencies and percent contributions; the types of transports are very different.

\subsection{Two-dimensional fields}

\subsubsection{Horizontal distributions}

Figure 8 shows the GEM column burden from the surface to approximately $500 \mathrm{hPa} ; 500 \mathrm{hPa}$ is the pressure level closest to the highest vertical level included in the column burden calculation from the GRAHM's terrain-following vertical coordinate system. Average winds are also shown. We show the GEM column burden up to $500 \mathrm{hPa}$ as we are interested in lower tropospheric mercury; it likely has the best chance to reach the surface and affect the biota. Furthermore, the column burden of this figure is consistent with the atmospheric levels analyzed in Sect. 3.1. The winds shown in Fig. 8 are the vertical average of the horizontal seasonallyaveraged winds at $925,850,700,600,500$ and $400 \mathrm{hPa}$. The lowest level, $925 \mathrm{hPa}$, is very close to the surface. Winds from the highest level, $400 \mathrm{hPa}$, are included since the pressure level corresponding to the highest model vertical level included in the column burden calculation is expected to vary spatially and surpass $500 \mathrm{hPa}$ frequently. The verticallyaveraged winds indicate how the lower tropospheric GEM is generally transported horizontally. Although actual transport consists of intermingled horizontal and vertical components, we discuss these components separately for the sake of simplicity. 


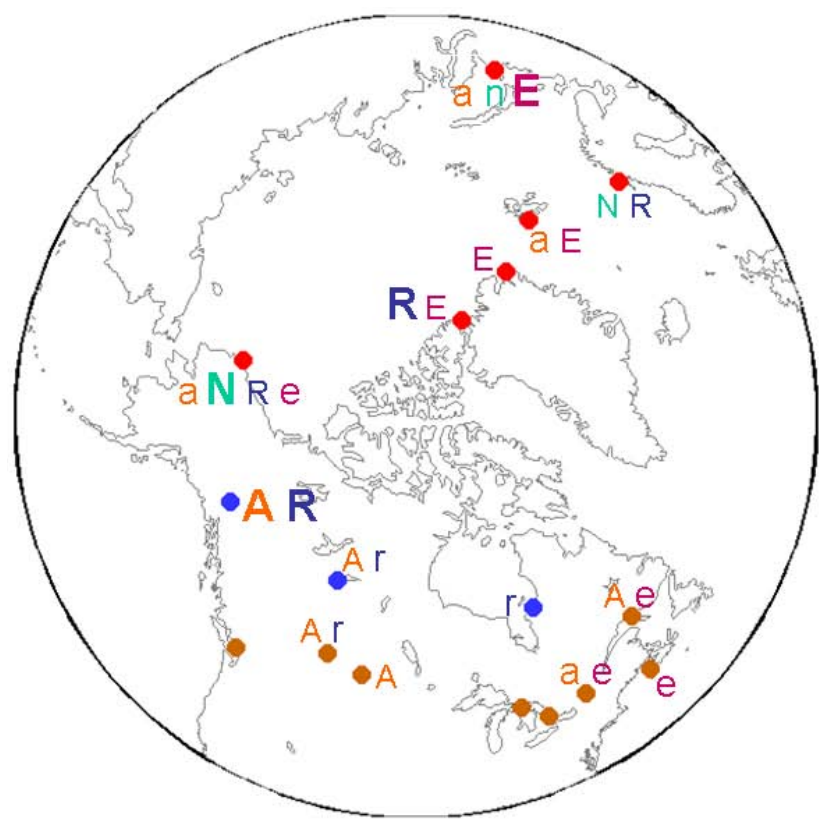

Fig. 7. This figure provides a visual representation of Table 4. Stations receiving the maximum, at least the 75 th percentile, and at least the median but less than the 75th percentile number of events from a given source region are assigned, respectively, a large uppercase letter, an upper-case letter, and a lower-case letter denoting the source region.

Long range transport of Asian mercury towards North America is clearly evident in Fig. 8's column burden of GEM from the surface to approximately $500 \mathrm{hPa}(\sim 5 \mathrm{~km})$. Spring and autumn transports are mainly zonal, with the latter stronger than the former. Summer experiences the strongest trans-Pacific transport, with the greatest burden of mercury transported, over the widest latitudinal band, and with the strongest penetration into western North America and the Arctic; increased summertime emissions from land surfaces have more than compensated for weaker trans-Pacific winds. These results are supported by Jiang et al. (2007), who found that Asian carbon monoxide concentrations over the north Pacific were highest in summer, followed by autumn then spring. The preference for Asian springtime LRT events at the midlatitude stations (see Sect. 3.1.5) seems to contradict the stronger summertime trans-Pacific transport of Fig. 8. It is likely that more mixing occurs during summer, so that fewer high concentration pollution plumes reach North America. This supposition is supported by Fig. 9, which indicates that the vertical gradient of Asian concentrations over the Pacific Ocean is smallest in summer at all latitude bands; convection, which is strongest in summer over the region of maximum Asian mercury emissions (Jiang et al., 2007), has mixed the atmosphere. Asian mercury is transported to the Arctic during summer and autumn, and gradually dissipates during winter and spring.
Table 4. Statistics pertaining to the number of long range transport events recorded over all verification stations over a year.

\begin{tabular}{lccc}
\hline Source region & Median & 75th percentile & Maximum \\
\hline Asia & 38 & 52 & 61 \\
North America & 11 & 14 & 25 \\
Russia & 20 & 24 & 33 \\
Europe & 1 & 5 & 27 \\
\hline
\end{tabular}

The North American mercury burden up to $5 \mathrm{~km}$ is transported primarily to the North Atlantic Ocean, and from there east to Europe and north to the Arctic. Lesser amounts of mercury are transported to the equatorial Pacific and also from the south coast of Alaska directly towards Barrow. North American mercury is transported less vigorously to Alert. Thus, these average winds fully explain Table 3's maximum and minimum number of North American LRT events recorded at Barrow and Alert, respectively.

Europe's mercury is transported mainly zonally and polewards, with a strong penetration into the Arctic during autumn and winter; the polewards direction of this transport produces the higher transport efficiencies at arctic stations during autumn and winter.

Most of the European LRT events recorded at arctic stations occurred during autumn and winter. During these seasons, Station Nord experiences average winds that have a westerly component. This component explains why Station Nord recorded so few European events compared to NyÅlesund, which receives a considerable amount of European mercury during both seasons.

It is not evident from these average winds precisely how the air masses responsible for the European LRT events recorded at the easternmost midlatitude stations travelled to these sites. With such a low event frequency, we cannot expect average wind fields to reveal the route. However, it seems most likely that the mercury-rich plumes crossed the Atlantic, given the stations' locations on the east coast. Since the events occurred mainly in spring and winter, it is likely that the Azores High was unusually weak during those times; such an anomalous atmospheric circulation would help the plumes to cross the Atlantic.

Russia's Arctic atmospheric burden is greatest in summer and autumn, possibly because of the summertime enhancement of land surface emissions, followed by winter. The high summer and autumn burdens possibly explain these seasons' strong Russian transport efficiencies reported in Sect. 3.1.4. The prevalence of wintertime Russian LRT events in the Arctic is possibly caused by the stronger wintertime winds; any LRT events produced by the equally strong spring winds are masked by AMDE dynamics (see Sect. 3.1.5). 
a) Asia: spring

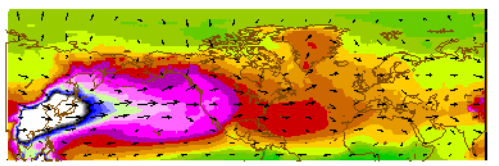

c) Asia: autumn

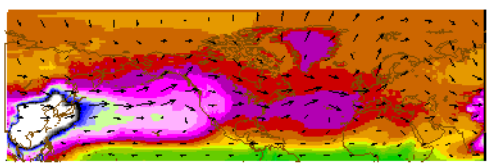

e) N America: spring

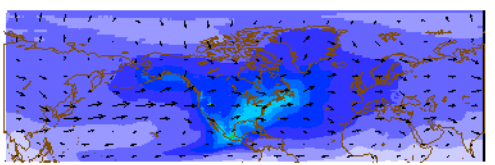

g) N America: autumn

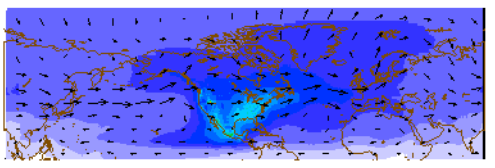

i) Russia: spring

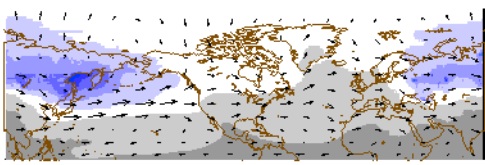

k) Russia: autumn

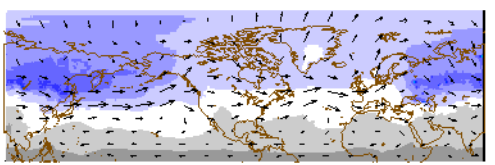

m) Europe: spring

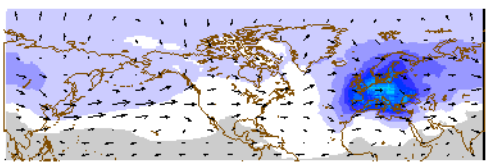

o) Europe: autumn

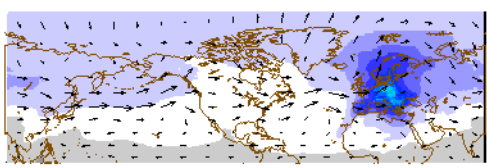

b) Asia: summer
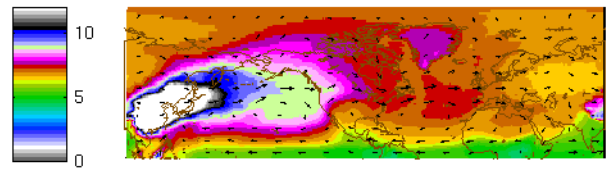

d) Asia: winter
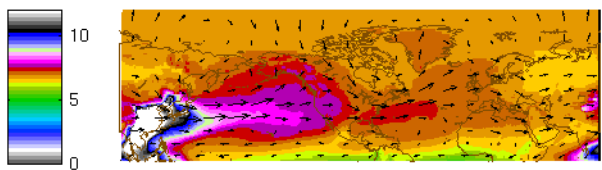

f) N America: summer
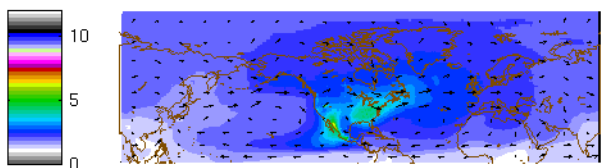

h) N America: winter
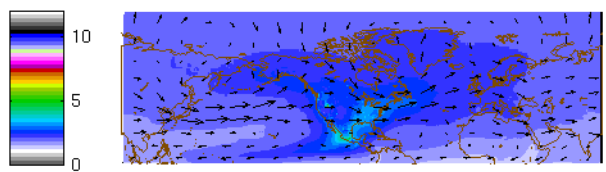

j) Russia: summer
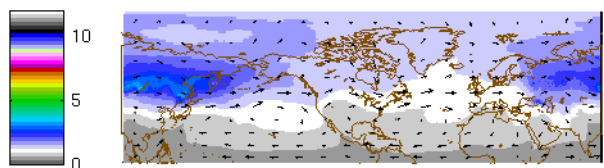

I) Russia: winter
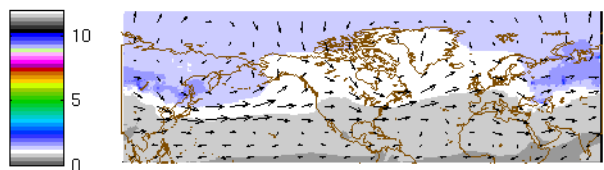

n) Europe: summer
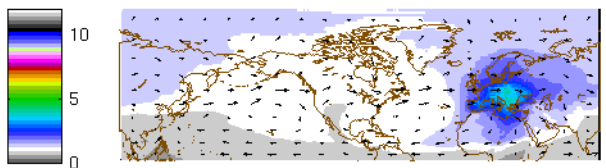

p) Europe: winter
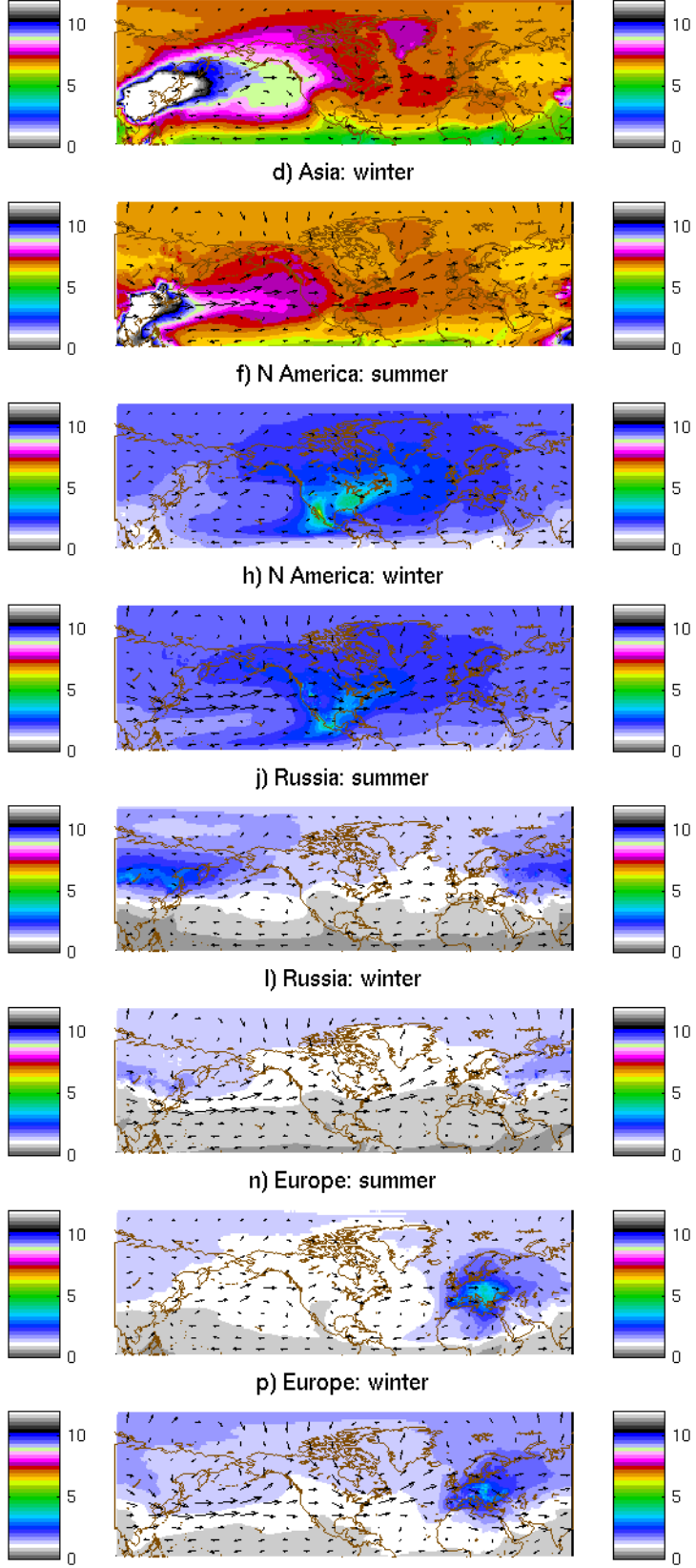

Fig. 8. Plotted for each source region and season for the year 2000 are: i) the GEM column burden (ng $\mathrm{m}^{-3}$ ) from the surface to 0.516 sigma $\left(\approx 523 \mathrm{hPa}\right.$; shading interval of $\left.0.3 \mathrm{ng} \mathrm{m}^{-3}\right)$, and ii) average wind directions and relative strengths calculated using winds from 925 to $400 \mathrm{hPa}$.

\subsubsection{Vertical distributions}

Asian, North American and Russian mercury concentrations tend to increase at all three latitude bands throughout the column during spring and summer and to dissipate through autumn and winter (Fig. 9). The spring/summer augmentation of values may be driven by increasing insolation, which, in turn, forces an increase in the natural land emissions and reemissions. Note that the zonal winds are at their weakest in each latitude band during summer. Europe's deviant behaviour with respect to this annual cycle may be caused by the fact that the model's annual non-anthropogenic emissions are smaller for Europe than any of the other three source regions, along with the fact that the model's European nonanthropogenic emissions are smaller than its anthropogenic emissions. 

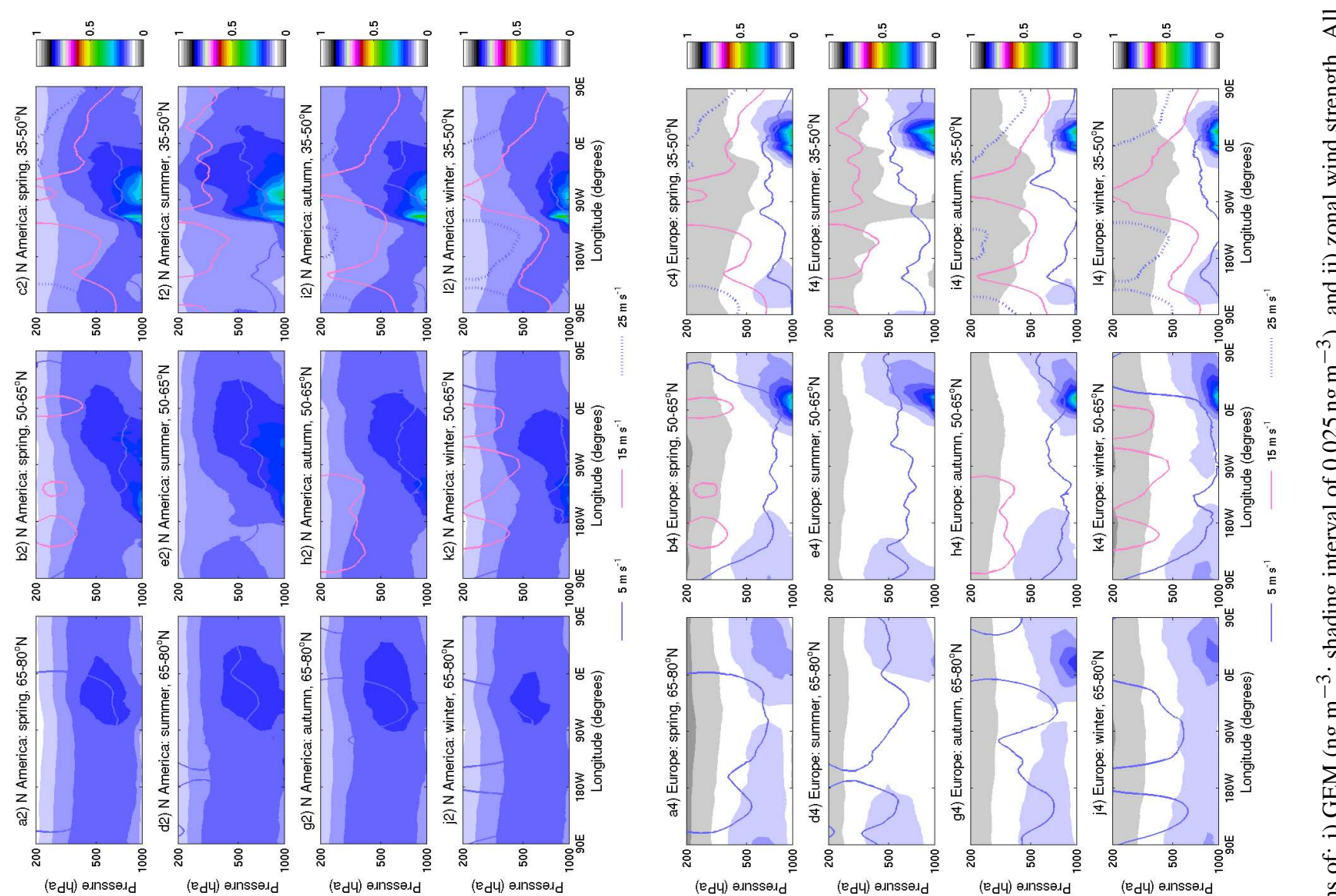

\section{IIIII}
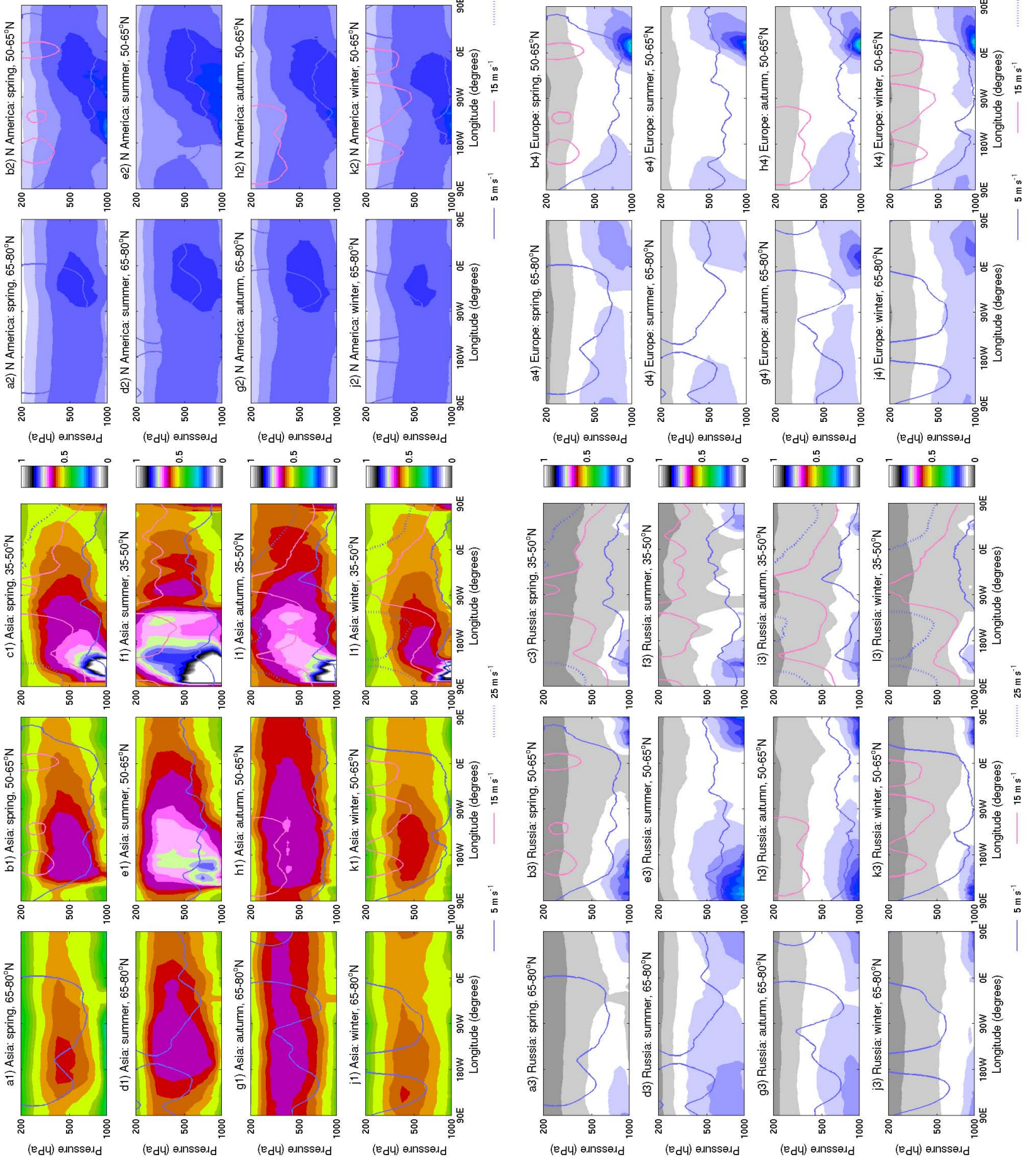

1
0
0
0
0
0
4
0
0
2
0
0
0
.3
0
0
0
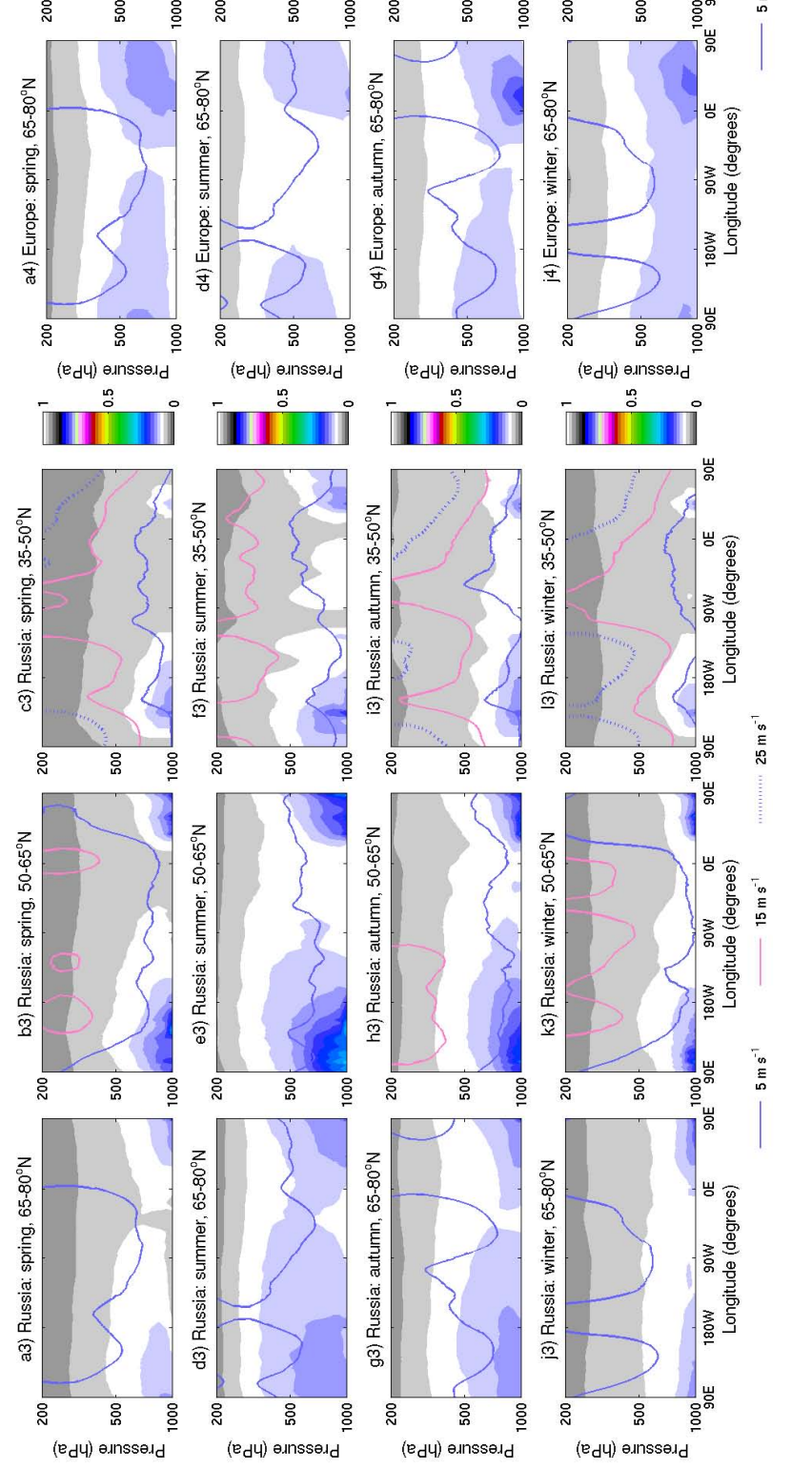

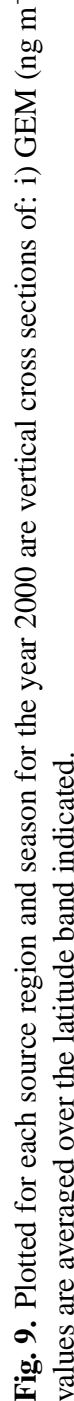


Maximum mercury concentrations for all source regions and all three latitude bands tend to be found in the mid troposphere when not directly over a source region. This seems to contradict the springtime GEM vertical profiles from the northeast Pacific that were measured by Radke et al. (2007). These profiles show small to strongly negative vertical gradients from the surface to $8 \mathrm{~km}$. Their lack of a midtropospheric maximum is probably a consequence of oceanic emissions increasing low-altitude concentrations; our source regions only include ocean emissions in coastal regions. Our mid-tropospheric maxima suggest, as was found by Strode et al. (2008) that the trans-Pacific transport of Asian mercury occurs preferentially at that level, although the transport descends to the surface. Weiss-Penzias et al. (2006) concluded that the trans-Pacific transport of mercury is more efficient at higher than lower altitudes. Similar results were reported by Liang et al. (2004) and Wang et al. (2009), who studied carbon monoxide transport, although the former study found that the trans-Pacific transport no longer reaches the surface in summer. This disagreement may be a consequence of the reduced summertime lifetime of carbon monoxide reported by the authors.

Asian concentrations decrease, while European and Russian concentrations increase with latitude band. For North America, the high concentration regions are most extensive in the $50^{\circ}-65^{\circ}$ band.

\section{Summary}

The base model run was able to reproduce observed ambient GEM concentrations fairly well at each of our 17 verification stations in the Arctic and across Canada. This indicates that meteorological and chemical processes governing the behaviour of mercury at these locations are fundamentally identical; the model was able to simulate the probable variation in these processes at the different sites without being tuned or adapted in any way.

Of our four source regions, we find that Asia is the dominant source of mercury at all stations, in all seasons, at all levels considered. Despite its relatively low transport efficiencies, it is characterized by the greatest percent contributions and tends to determine most of the base run's variability. It generated the most LRT events. North America behaves as a local source at the subarctic and midlatitude stations, with a tendency to contribute more mercury at the surface than in the mid-troposphere, determine the base run's variability, and exhibit the largest surface-level transport efficiencies. Similarly, Europe is a local source at Andoya and Russia at Amderma.

Considering transport to the Arctic, we find that Russian transport efficiencies are important, as expected, particularly in summer and autumn. However, our European efficiencies are lower and Asian efficiencies higher than those found in the literature. This unexpected result is likely explained by fact that most studies of transport to the Arctic concern aerosols and carbon monoxide. The transport of these two pollutants favours closer sources since their lifetimes are far shorter than that of mercury.

The accepted springtime preference for the trans-Pacific transport of Asian pollution was evident only in the midlatitude group of stations, being masked in the arctic and subarctic groups by the occurrence of AMDEs. Although LRT events from specific source regions tended to be recorded preferentially in certain regions, for instance Russian events at the western stations of the subarctic and midlatitude groups, we estimate that the dynamics and transport pathways affecting mercury concentrations at two separate arctic locations are not defined by proximity alone.

We find that the column burden of GEM in the lowest $5 \mathrm{~km}$ is largest in summer for Asia, North America and Russia, but in winter for Europe. In the vertical, transport of mercury from all source regions occurred principally in the midtroposphere in all three latitude bands considered.

Acknowledgements. This research was funded by the Government of Canada's International Polar Year (IPY) project, Intercontinental Atmospheric Transport of Anthropogenic Pollutants to the Arctic (INCATPA). We are grateful to all those who provided data. Henrik Skov is acknowledged for the GEM concentrations from Station Nord; the Danish Environmental Protection Agency financially supported his work with means from the MIKA/DANCEA funds for Environmental Support to the Arctic Region. We are also indebted to AMAP for providing us with the gridded version of their anthropogenic mercury emission data. We thank Hayley Hung, Alexandra Steffen, Pierrette Blanchard and the two anonymous reviewers for their helpful and insightful comments that significantly improved this manuscript.

Edited by: R. Ebinghaus

\section{References}

Almeida, M. D., Lacerda, L. D., Bastos, W. R., and Herrmann, J. C.: Mercury loss from soils following conversion from forest to pasture in Rondonia, Western Amazon, Brazil, Environ. Pollut., 137, 179-186, 2005.

Berg, T., Aspmo, K., and Steinnes, E.: Transport of Hg from atmospheric mercury depletion events to the mainland of Norway and its possible influence on $\mathrm{Hg}$ deposition, Geophys. Res. Lett., 35, L09802, doi:10.1029/2008GL033586, 2008.

Bertschi, I. T. and Jaffe, D. A.: Long-range transport of ozone, carbon monoxide, and aerosols to the NE Pacific troposphere during the summer of 2003: Observations of smoke plumes from Asian boreal fires, J. Geophys. Res., 110, D05303, doi:10.1029/2004JD005135, 2005.

Côté, J., Desmarais, J.-G., Gravel, S., Méthot, A., Patoine, A., Roch, M., and Staniforth, A.: The operational CMC-MRB Global Environmental Multiscale (GEM) Model: Part II - Results, Mon. Weather Rev., 126, 1397-1418, 1998a.

Côté, J., Gravel, S., Méthot, A., Patoine, A., Roch, M., and Staniforth, A.: The operational CMC-MRB Global Environmental 
Multiscale (GEM) Model: Part I - Design considerations and formulation, Mon. Weather Rev., 126, 1373-1395, 1998 b.

Dastoor, A. P., Davignon, D., Theys, N., Van Roozendael, M., Steffen, A., and Ariya, P. A.: Modeling dynamic exchange of gaseous elemental mercury at polar sunrise, Environ. Sci. Technol., 42, 5183-5188, 2008.

Dastoor, A. P. and Larocque, Y.: Global circulation of atmospheric mercury: a modelling study, Atmos. Environ., 38, 147-161, 2004.

Ding, A., Wang, T., Xue, L., Gao, J., Stohl, A., Lei, H., Jin, D., Ren, Y., Wang, X., Wei, X., Qui, Y., Liu, J., and Zhang, X.: Transport of north China air pollution by midlatitude cyclones: Case study of aircraft measurements in summer 2007, J. Geophys. Res., 114, D11399, doi:10.1029/2009JD012339, 2009.

Eleftheriadis, K., Vratolis, S., and Nyeki, S.: Aerosol black carbon in the European Arctic: Measurements at Zeppelin station, Ny-Ålesund, Svalbard from 1998-2007, Geophys. Res. Lett., 36, L02809, doi:10.1029/2008GL035741, 2009.

Faïn, X., Obrist, D., Hallar, A. G., Mccubbin, I., and Rahn, T.: High levels of reactive gaseous mercury observed at a high elevation research laboratory in the Rocky Mountains, Atmos. Chem. Phys., 9, 8049-8060, doi:10.5194/acp-9-8049-2009, 2009.

Fitzgerald, W. F., Engstrom, D. R., Lamborg, C. H., Tseng, C.-M., Balcom, P. H., and Hammerschmidt, C. R.: Modern and historic atmospheric mercury fluxes in northern Alaska: Global sources and Arctic depletion, Environ. Sci. Technol., 39, 557-568, 2005.

Fouquart, Y. and Bonnel, B.: Computations of solar heating of the earth's atmosphere: a new parameterization, Contrib. Atmos. Phys., 53, 35-62, 1980.

Garand, L. and Mailhot, J.: The influence of infrared radiation on numerical weather forecasts, in: Proceedings of the Seventh Conference on Atmospheric Radiation, San Francisco, USA, 2327 July 1990, J146-J151, 1990.

Gbor, P. K., Wen, D., Meng, F., Yang, F., and Sloan, J. J.: Modeling of mercury emission, transport and deposition in North America, Atmos. Environ., 41, 1135-1149, 2007.

Goulet, R. R., Holmes, J., Page, B., Poissant, L., Siciliano, S. D., Lean, D. R. S., Wang, F., Amyot, M., and Tessier, A.: Mercury transformations and fluxes in sediments of a riverine wetland, Geochim. Cosmochim. Ac., 71, 3393-3406, 2007.

Jaffe, D., Prestbo, E., Swartzendruber, P., Weiss-Penzias, P., Kato, S., Takami, A., Hatakeyama, S., and Kajii, Y.: Export of atmospheric mercury from Asia, Atmos. Environ., 39, 3029-3038, 2005.

Jiang, J. H., Livesey, N. J., Su, H., Neary, L., McConnell, J. C., and Richards, N. A. D.: Connecting surface emissions, convective uplifting, and long-range transport of carbon monoxide in the upper troposphere: New observations from the Aura Microwave Limb Sounder, Geophys. Res. Lett., 34, L18812, doi:10.1029/2007GL030638, 2007.

Kim, K.-H., Ebinghaus, R., Schroeder, W. H., Blanchard, P., Kock, H. H., Steffen, A., Froude, F. A., Kim, M.-Y., Hong, S., and Kim, J.-H.: Atmospheric mercury concentrations from several observatory sites in the Northern Hemisphere, J. Atmos. Chem., 50, 1-24, 2005.

Law, K. S. and Stohl, A.: Arctic air pollution: origins and impacts, Science, 315, 1537-1540, 2007.

Lehrer, E., Hönninger, G., and Platt, U.: A one dimensional model study of the mechanism of halogen liberation and vertical trans- port in the polar troposphere, Atmos. Chem. Phys., 4, 24272440, doi:10.5194/acp-4-2427-2004, 2004.

Liang, Q., Jaeglé, L., Jaffe, D. A., Weiss-Penzias, P., Heckman, A., and Snow, J. A.: Long-range transport of Asian pollution to the northeast Pacific: Seasonal variations and transport pathways of carbon monoxide, J. Geophys. Res., 109, D23S07, doi:10.1029/2003JD004402, 2004.

Lin, C.-J., Cheng, M.-D., and Schroeder, W. H.: Transport patterns and potential sources of total gaseous mercury measured in Canadian high Arctic in 1995, Atmos. Environ., 35, 1141-1154, 2001.

Lin, C.-J., Pongprueksa, P., Lindberg, S. E., Pehkonen, S. O., Byun, D., and Jang, C.: Scientific uncertainties in atmospheric mercury models I: Model science evaluation, Atmos. Environ., 40, 29112928, 2006.

Lohman, K., Seigneur, C., Gustin, M., and Lindberg, S.: Sensitivity of the global atmospheric cycle of mercury to emissions, Appl. Geochem., 23, 454-466, 2008.

Mason, R.: Mercury emissions from natural processes and their importance in the global mercury cycle, Mercury fate and transport in the global atmosphere, Springer US, 173-191, 2009.

Mitchell, C. P. J., Branfireun, B. A., and Kolka, R. K.: Assessing sulfate and carbon controls on net methylmercury production in peatlands: An in situ mesocosm approach, Appl. Geochem., 23, 503-518, 2008.

Pacyna, E. G., Pacyna, J. M., Steenhuisen, F., and Wilson, S.: Global anthropogenic mercury emission inventory for 2000, Atmos. Environ., 40, 4048-4063, 2006.

Pacyna, E. G., Pacyna, J. M., Sundseth, K., Munthe, J., Kindbom, K., Wilson, S., Steenhuisen, F., Maxson, P.: Global emission of mercury to the atmosphere from anthropogenic sources in 2005 and projections to 2020, Atmos. Environ., 44, 2487-2499, 2010.

Pacyna, J. M., Pacyna, E. G., Steenhuisen, F., and Wilson, S.: Mapping 1995 global anthropogenic emissions of mercury, Atmos. Environ., 37, 109-117, 2003.

Radke, L. F., Friedli, H. R., and Heikes, B. G.: Atmospheric mercury over the NE Pacific during spring 2002: Gradients, residence time, upper troposphere lower stratosphere loss, and long-range transport, J. Geophys. Res., 112, D19305, doi:10.1029/2005JD005828, 2007.

Ryaboshapko, A., Bullock Jr., O. R., Christensen, J., Cohen, M., Dastoor, A., Ilyin, I., Petersen, G., Syrakov, D., Artz, R., Davignon, D., Draxler, R. R., and Munthe, J.: Intercomparison study of atmospheric mercury models: 1 . Comparison of models with short-term measurements, Sci. Total Environ., 376, 228-240, 2007a.

Ryaboshapko, A., Bullock Jr., O. R., Christensen, J., Cohen, M., Dastoor, A., Ilyin, I., Petersen, G., Syrakov, D., Travnikov, O., Artz, R., Davignon, D., Draxler, R. R., Munthe, J., and Pacyna, J.: Intercomparison study of atmospheric mercury models: 2 . Modelling results vs. long-term observations and comparison of country deposition budgets, Sci. Total Environ., 377, 319-333, $2007 b$.

Schroeder, W. H. and Munthe, J.: Atmospheric mercury - an overview, Atmos. Environ., 32, 809-822, 1998.

Shetty, S. K., Lin, C.-J., Streets, D. G., and Jang, C.: Model estimate of mercury emission from natural sources in East Asia, Atmos. Environ., 42, 8674-8685, 2008.

Shindell, D. T., Chin, M., Dentener, F., Doherty, R. M., Faluvegi, G., Fiore, A. M., Hess, P., Koch, D. M., MacKenzie, I. A., 
Sanderson, M. G., Schultz, M. G., Schulz, M., Stevenson, D. S., Teich, H., Textor, C., Wild, O., Bergmann, D. J., Bey, I., Bian, H., Cuvelier, C., Duncan, B. N., Folberth, G., Horowitz, L. W., Jonson, J., Kaminski, J. W., Marmer, E., Park, R., Pringle, K. J., Schroeder, S., Szopa, S., Takemura, T., Zeng, G., Keating, T. J., and Zuber, A.: A multi-model assessment of pollution transport to the Arctic, Atmos. Chem. Phys., 8, 5353-5372, doi:10.5194/acp-8-5353-2008, 2008.

Steen, A. O., Berg, T., Dastoor, A. P., Durnford, D. A., Hole, L. R., and Pfaffhuber, K. A.: Dynamic exchange of gaseous elemental mercury during polar night and day, Atmos. Environ., 43, 56045610, 2009.

Steffen, A., Schroeder, W., Macdonald, R., Poissant, L., and Konoplev, A.: Mercury in the Arctic atmosphere: An analysis of eight years of measurements of GEM at Alert (Canada) and a comparison with observations at Amderma (Russia) and Kuujjuarapik (Canada), Sci. Total Environ., 342, 185-198, 2005.

Stohl, A.: Characteristics of atmospheric transport into the Arctic troposphere, J. Geophys. Res., 111, D11306, doi:10.1029/2005JD006888, 2006.

Stohl, A., Eckhardt, S., Forster, C., James, P., and Spichtinger, N.: On the pathways and timescales of intercontinental air pollution transport, J. Geophys. Res., 107, 4684, doi:10.1029/2001JD001396, 2002.

Strode, S. A., Jaeglé, L., Jaffe, D. A., Swartzendruber, P. C., Selin, N. E., Holmes, C., and Yantosca, R. M.: TransPacific transport of mercury, J. Geophys. Res., 113, D15305, doi:10.1029/2007JD009428, 2008.

Sunderland, E. M., Krabbenhoft, D. P., Moreau, J. W., Strode, S. A., and Landing, W. M.: Mercury sources, distribution, and bioavailability in the North Pacific Ocean: Insights from data and models, Global Biogeochem. Cy., 23, GB2010, doi:10.1029/2008GB003425, 2009.

Swartzendruber, P. C., Jaffe, D. A., and Finley, B.: Improved fluorescence peak integration in the Tekran 2537 for applications with sub-optimal sample loadings, Atmos. Environ., 43, 36483651, 2009.
Travnikov, O.: Contribution of the intercontinental atmospheric transport to mercury pollution in the Northern Hemisphere, Atmos. Environ., 39, 7541-7548, 2005.

Wang, K., Zhang, Y., Jang, C., Phillips, S., and Wang, B.: Modeling intercontinental air pollution transport over the transPacific region in 2001 using the Community Multiscale Air Quality modeling system, J. Geophys. Res., 114, D04307, doi:10.1029/2008JD010807, 2009.

Warneke, C., Bahreini, R., Brioude, J., Brock, C. A., de Gouw, J. A., Fahey, D. W., Froyd, K. D., Holloway, J. S., Middlebrook, A., Miller, L., Montzka, S., Murphy, D. M., Peischl, J., Ryerson, T. B., Schwarz, J. P., Spackman, J. R., and Veres, P.: Biomass burning in Siberia and Kazakhstan as an important source for haze over the Alaskan Arctic in April 2008, Geophys. Res. Lett., 36, L02813, doi:10.1029/2008GL036194, 2009.

Weiss-Penzias, P., Jaffe, D. A., Swartzendruber, P., Dennison, J. B., Chand, D., Hafner, W., and Prestbo, E.: Observations of Asian air pollution in the free troposphere at Mount Bachelor Observatory during the spring of 2004, J. Geophys. Res., 111, D10304, doi:10.1029/2005JD006522, 2006.

Weiss-Penzias, P., Jaffe, D., Swartzendruber, P., Hafner, W., Chand, D., and Prestbo, E.: Quantifying Asian.and biomass burning sources of mercury using the $\mathrm{Hg} / \mathrm{CO}$ ratio in pollution plumes observed at the Mount Bachelor Observatory, Atmos. Environ., 41, 4366-4379, 2007.

Zhang, L., Brook, J. R., and Vet, R.: A revised parameterization for gaseous dry deposition in air-quality models, Atmos. Chem. Phys., 3, 2067-2082, doi:10.5194/acp-3-2067-2003, 2003.

Zhang, L., Gong, S., Padro, J., and Barrie, L. A.: A size-segregated particle dry deposition scheme for an atmospheric aerosol module, Atmos. Environ., 35, 549-560, 2001. 